\section{ECOPITOR}

Make Your Publications Visible.
A Service of

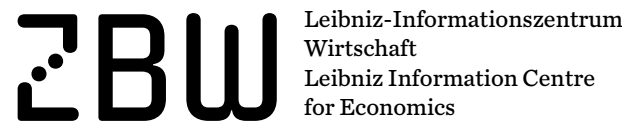

Cavallo, Michele; Tille, Cedric

\title{
Working Paper \\ Could capital gains smooth a current account rebalancing?
}

Staff Report, No. 237

Provided in Cooperation with:

Federal Reserve Bank of New York

Suggested Citation: Cavallo, Michele; Tille, Cedric (2006) : Could capital gains smooth a current account rebalancing?, Staff Report, No. 237, Federal Reserve Bank of New York, New York, NY

This Version is available at:

http://hdl.handle.net/10419/60559

Standard-Nutzungsbedingungen:

Die Dokumente auf EconStor dürfen zu eigenen wissenschaftlichen Zwecken und zum Privatgebrauch gespeichert und kopiert werden.

Sie dürfen die Dokumente nicht für öffentliche oder kommerzielle Zwecke vervielfältigen, öffentlich ausstellen, öffentlich zugänglich machen, vertreiben oder anderweitig nutzen.

Sofern die Verfasser die Dokumente unter Open-Content-Lizenzen (insbesondere CC-Lizenzen) zur Verfügung gestellt haben sollten, gelten abweichend von diesen Nutzungsbedingungen die in der dort genannten Lizenz gewährten Nutzungsrechte.
Terms of use:

Documents in EconStor may be saved and copied for your personal and scholarly purposes.

You are not to copy documents for public or commercial purposes, to exhibit the documents publicly, to make them publicly available on the internet, or to distribute or otherwise use the documents in public.

If the documents have been made available under an Open Content Licence (especially Creative Commons Licences), you may exercise further usage rights as specified in the indicated licence. 


\title{
Federal Reserve Bank of New York Staff Reports
}

\section{Could Capital Gains Smooth a Current Account Rebalancing?}

\author{
Michele Cavallo \\ Cédric Tille
}

\author{
Staff Report no. 237 \\ January 2006
}

This paper presents preliminary findings and is being distributed to economists and other interested readers solely to stimulate discussion and elicit comments. The views expressed in the paper are those of the authors and are not necessarily reflective of views at the Federal Reserve Bank of New York or the Federal Reserve System. Any errors or omissions are the responsibility of the authors. 


\author{
Could Capital Gains Smooth a Current Account Rebalancing? \\ Michele Cavallo and Cédric Tille \\ Federal Reserve Bank of New York Staff Reports, no. 237 \\ January 2006 \\ JEL classification: F31, F32, F41
}

\begin{abstract}
A narrowing of the U.S. current account deficit through exchange rate movements is likely to entail a substantial depreciation of the dollar, as stressed in research by Obstfeld and Rogoff. We assess how the adjustment is affected by the high degree of financial integration in the world economy. A growing body of research emphasizes the increasing leverage in international financial positions, with industrialized economies holding substantial and growing financial claims on each other. Exchange rate movements then lead to valuation effects as the currency composition of a country's assets and liabilities are not matched. In particular, a dollar depreciation generates valuation gains for the United States by boosting the dollar value of much of its foreign-currency-denominated assets. We consider an adjustment scenario in which the U.S. net external debt is held constant. The key finding is that as the current account moves into balance, the pace of adjustment is smooth. Intuitively, the valuation gains from the depreciation of the dollar allow the United States to finance ongoing, albeit shrinking, current account deficits. We find that the smooth pattern of adjustment is robust to alternative scenarios, although the ultimate movements in exchange rates will vary under different conditions.
\end{abstract}

Key words: current account, exchange rates, global imbalances

Cavallo: Federal Reserve Bank of San Francisco (e-mail: michele.cavallo@sf.frb.org). Tille: Federal Reserve Bank of New York (cedric.tille@ny.frb.org). The authors thank Pierre-Olivier Gourinchas, Luca Guerrieri, Maurice Obstfeld, Alessandro Rebucci, Kenneth Rogoff, and Mark Spiegel for helpful feedback; seminar participants at the Fall 2005 Federal Reserve SCIEA meeting and the Graduate Institute of International Studies, Geneva (HEI) for valuable comments; and Thien Nguyen for excellent research assistance. The views expressed in this paper are those of the authors and do not necessarily reflect the position of the Federal Reserve Bank of San Francisco, the Federal Reserve Bank of New York, or the Federal Reserve System. 


\section{Introduction}

A central feature of the global economy is the extent of international imbalances, mainly the large and growing current account deficit of the United States. The U.S. external deficit increased gradually in the early 1990s to reach a moderate level of 1.7 percent of GDP in 1997 (Figure 1, solid line), and subsequently widened at a fast pace, hitting 5.7 percent of GDP in 2004. This substantial borrowing from the rest of the world has pushed the U.S. into a substantial net debt vis-à-vis foreign investors, with the net liabilities amounting to 21.7 percent of GDP at the end of 2004 (Figure 1, dashed line).

The sustainability of this situation, as well as the pattern of an eventual adjustment, are the objects of substantial analysis and debate, with the volume by Clarida (2006) providing an overview of the various positions. Overall there is a consensus that the international imbalances will eventually unwind. Whether this adjustment is likely to occur smoothly, or to be sudden and disruptive, remains debated. Several economists argue that the current situation is driven by policy choices that are likely to persist over several years (Dooley et al., 2005, 2006), and that the U.S. is not condemned to face a disruptive adjustment in order to stabilize its borrowing (Backus et al., 2005). The U.S. may also have better growth prospects than the rest of the world, leading it to account for a permanently higher share of world GDP. In this situation foreign investors increase the share of U.S. assets in their portfolio, leading to sustained U.S. deficits, with a gradual adjustment once the portfolio re-allocation has run its course (Engel and Rogers, 2006). Another scenario is that the U.S. financial sector has an advantage in intermediating world savings. Under this scenario, the transit of world savings through the U.S. to be converted into investment leads to sustained current account imbalances (Caballero, Farhi and Gourinchas, 2005).

On the other side of the debate, many argue that the current situation is not sustainable and will lead to a substantial depreciation of the dollar vis-à-vis other currencies. This adjustment can 
be gradual and relatively benign (Blanchard, Giavazzi, and Sa, 2005, Helbling et al., 2005, Faruqee et al., 2006). Several contributions however point to the risk of a rapid adjustment, with disruptive consequences for the world economy (Obstfeld and Rogoff, 2005, 2006, Roubini and Setser, 2005). A representative, and widely-cited contribution of the later view is the work by Obstfeld and Rogoff (2005, 2006). They show that the return of the U.S. current account deficit to balance entails a depreciation of the U.S. dollar of 30-35 percent against the main world currencies. In addition, they argue that such an adjustment could take place in a disruptive manner if stemming from a loss of confidence by foreign investors in the U.S. economy.

Exchange rate movements play a central role in most scenario of international adjustment, with a depreciation of the dollar in real terms (i.e., even when adjusted for inflation differentials). First, a depreciation improves the competitiveness of U.S. goods in world markets by making them cheaper, relative to foreign goods. As a result, consumer worldwide re-allocate their consumption towards U.S. goods, thereby boosting U.S. exports and reducing its imports. Second, and more importantly, a real depreciation implies that the price of non-traded goods in the U.S. (such as services) falls relative to the price of traded goods (such as manufactured goods), inducing U.S. consumers to re-allocate their purchases towards non-traded goods. Obstfeld and Rogoff $(2005,2006)$ point that this second channel plays a key role in the adjustment.

The contribution of this paper is to assess how the adjustment of the U.S. current account deficit interacts with the high degree of financial integration in the world economy. A growing body of research points that the degree of financial integration has dramatically increased since the early 1990s (Gourinchas and Rey, 2005, 2006, Lane and Milesi-Ferretti, 2003, 2005, 2006, Obstfeld, 2004, Tille, 2003, 2005). The world has moved from a situation where net positions were dominant, with some countries being creditors and other debtors, to a situation where cross-holdings of financial assets across countries have surged, with the values of gross assets and liabilities positions dwarfing 
the value of net positions. This development has opened a new channel through which exchange rate movements affect the world economies, namely the so-called valuation effect. If countries are leveraged in terms of currencies, with the currency composition of their assets differing from that of their liabilities, exchange rate fluctuations have a different effect on the two sides of the balance sheet, leading to sizable capital gains and losses in net terms. This mechanism is illustrated by the case of the United States: while U.S. liabilities are nearly exclusively denominated in dollars, about two-thirds of U.S. assets are denominated in foreign currencies (Tille, 2005). A depreciation of the dollar then leads to a capital gain for the U.S., as it boosts the dollar value of a given amount of foreign-currency assets. This valuation channel is playing an increasingly large role in driving the U.S. net investment position. Indeed, Figure 1 shows an apparently puzzling pattern with the U.S. net international debt remaining steady at 20-25 percent of GDP over the last three years despite a current account deficit in the order of 5 percent of GDP. This odd pattern is a consequence of the valuation effect of exchange rate movements. Figure 2 shows the change in the net international investment position of the U.S. over the last 20 years. The solid line represents the total change, which is driven by several factors. First, net financial flows (the first bars from the left) consistently pushed the U.S. into debt, reflecting the increasingly large current account deficits. Second, the valuation effects of exchange rate movements (the second bars from the left) substantially affected the U.S. position. In particular, the depreciation of the dollar since 2002 generated capital gains that amount to about two-thirds of the current account deficit. Other factors driving the U.S. net positions, such as movements in asset prices (the second bars from the right) and changes in data coverage (the first bars from the right) played a relatively smaller role.

While some analyses of a narrowing of the U.S. current account deficit take financial integration into account, they do so in a way that limits its role. ${ }^{1}$ In particular, Obstfeld and Rogoff (2005,

\footnotetext{
${ }^{1}$ The valuation effects are incorporated in the analyses of Blanchard et al. (2005) and Obstfeld and Rogoff (2005, 2006).
} 
2006) argue that taking into account the valuation effect of exchange rate movements reduces the required depreciation of the dollar only modestly. This modest effect reflects the exact nature of their experiment. Abstracting from valuation effects, the stabilization of U.S. net external debt at its current level requires the current account to move into balance. When taking valuation effects into account, Obstfeld and Rogoff still require the current account to move immediately into balance. This generates a valuation effect that substantially improves the U.S. position, reducing U.S. net external debt by a factor of three, but has a limited impact on the magnitude of the exchange rate movement.

The magnitude of exchange rate movements is however only one dimension of adjustment. Another aspect is the pace of these movements, with a given adjustment being less likely to be disruptive if spread over several years. For instance, a 30 percent depreciation of the dollar would entail more adverse effects if concentrated over a year than if smoothed over a decade. Our paper focuses on this dimension by considering an alternative experiment. Rather than immediately bringing the current account to zero, we consider a scenario where U.S. net external debt is kept constant. We regard such a scenario as realistic, as the current level of U.S. net external debt has so far proved manageable. We find that the presence of valuation effects then allows for a "smooth landing" with the U.S. current account imbalance gradually disappearing.

Intuitively, the smooth pattern of the adjustment reflects the fact that the capital gains stemming from the depreciation of the dollar are now used to finance ongoing, albeit shrinking, current account deficits during the adjustment. In the first year of the adjustment, the dollar depreciates, generating a capital gain through the valuation effect. This gain is used to finance net imports, so the current account does not have to fall to zero immediately. This reduces the pressure on the exchange rate in the first year, with the dollar depreciating by only 9 percent. In the second year of the adjustment, this pattern is repeated, with a further narrowing of the current account deficit, and 
a dollar depreciation reaching 15 percent from the initial situation. Our adjustment scenario does ultimately bring the current account to balance, as this is the only way to stabilize the U.S. net debt once the world economy has reached a new steady path. However, the adjustment is quite gradual, with the current account deficit halving in three years.

An important feature of our scenario is that while net international asset positions are kept constant, the values of gross assets and liabilities increased substantially. There is therefore a large, and increasing, amount of leverage in international balance sheets. This dimension is beneficial to the U.S. as we assume that it earns a higher rate of return on its assets than it pays on its liabilities, an "exorbitant privilege" discussed by Gourinchas and Rey (2006), and Lane and MilesiFerretti (2006). To assess the sensitivity of our results to this increased leverage, we complement our baseline scenario by considering two alternatives. In the first one, we set financial flows to zero so leverage is kept constant. In the second one, we increase the rate of return on U.S. liabilities to match the rate on U.S. assets. The magnitude of exchange rate movements is larger under both alternative scenarios, and especially under the alternative of interest rate convergence where the dollar depreciation is boosted by one-third. Interestingly, the gradual nature of adjustment remains robust, with the U.S. current account deficit only halving in 3-4 years. The composition of adjustment is different however. In particular the U.S. trade balance adjusts faster under the alternative scenarios, as the U.S. is not shielded from the interest burden on its liabilities any longer.

The remainder of the paper is organized as follows. Section 2 describes the key elements of our model. Section 3 presents our adjustment scenario, as well as a sensitivity analysis to alternative scenarios. Section 4 concludes.

\section{A three-country model of interdependence}

As our analysis is based on the work of Obstfeld and Rogoff (2005), this section focuses on the main elements of setup and the dimensions along which we extend their model. More details are 
given in the Appendix.

\subsection{Consumption allocation and relative prices}

The model economy consists of three regions: the U.S., Europe, and Asia, which are indexed by $U, E$, and $A$, respectively. The regions are linked by trade flows and by cross-holdings of financial instruments. Each region produces a traded good and a non-traded good, with the three traded goods being imperfect substitutes. The aggregate consumption index in region $i$, denoted by $C^{i}$, is given by:

$$
C^{i}=\left[\gamma^{\frac{1}{\theta}}\left(C_{T}^{i}\right)^{\frac{\theta-1}{\theta}}+(1-\gamma)^{\frac{1}{\theta}}\left(C_{N}^{i}\right)^{\frac{\theta-1}{\theta}}\right]^{\frac{\theta}{\theta-1}}, \quad i=U, E, A
$$

where $C_{T}^{i}$ represents a consumption index of domestic and foreign traded goods, and $C_{N}^{i}$ denotes consumption of the domestic non-traded good. The parameter $\theta$ represents the elasticity of substitution between traded and non-traded goods, with $\gamma$ and $1-\gamma$ being their respective shares in consumption. The consumption index of traded goods, $C_{T}^{i}$, includes the consumption of goods made in the U.S., Europe, and Asia, denoted by $C_{U}^{i}, C_{E}^{i}$, and $C_{A}^{i}$ respectively. The exact specification of the baskets of traded goods consumption in the three regions, $C_{T}^{U}, C_{T}^{E}$, and $C_{T}^{A}$, is given by:

$$
\begin{aligned}
& C_{T}^{U}=\left[\alpha^{\frac{1}{\eta}}\left(C_{U}^{U}\right)^{\frac{\eta-1}{\eta}}+(\beta-\alpha)^{\frac{1}{\eta}}\left(C_{E}^{U}\right)^{\frac{\eta-1}{\eta}}+(1-\beta)^{\frac{1}{\eta}}\left(C_{A}^{U}\right)^{\frac{\eta-1}{\eta}}\right]^{\frac{\eta}{\eta-1}}, \\
& C_{T}^{E}=\left[(\beta-\alpha)^{\frac{1}{\eta}}\left(C_{U}^{E}\right)^{\frac{\eta-1}{\eta}}+\alpha^{\frac{1}{\eta}}\left(C_{E}^{E}\right)^{\frac{\eta-1}{\eta}}+(1-\beta)^{\frac{1}{\eta}}\left(C_{A}^{E}\right)^{\frac{\eta-1}{\eta}}\right]^{\frac{\eta}{\eta-1}}, \\
& C_{T}^{A}=\left[\left(\frac{1-\delta}{2}\right)^{\frac{1}{\eta}}\left(C_{U}^{A}\right)^{\frac{\eta-1}{\eta}}+\left(\frac{1-\delta}{2}\right)^{\frac{1}{\eta}}\left(C_{E}^{A}\right)^{\frac{\eta-1}{\eta}}+\delta^{\frac{1}{\eta}}\left(C_{A}^{A}\right)^{\frac{\eta-1}{\eta}}\right]^{\frac{\eta}{\eta-1}},
\end{aligned}
$$

The parameter $\eta$ represents the elasticity of substitution between various traded goods. In the U.S. and Europe, domestically produced goods represent a share $\alpha$ of the aggregate consumption of tradable goods, with the goods produced in the other non-Asia region representing a share equal to $\beta-\alpha$. Asian-produced goods represent a share $1-\beta$ of the traded basket, both in the U.S. 
and Europe. U.S.- and European-made goods each represent a share $(1-\delta) / 2$ of the Asian basket of traded goods consumption, with Asian-made goods accounting for the remaining share, $\delta$. We adopt the parametrization of Obstfeld and Rogoff (2005) where $1>\beta>\alpha>0.5$, and $\delta>0.5$. This implies a home bias in traded goods consumption, i.e. each country has a relative preference for domestically produced good.

Based on the consumption baskets (1)-(4), we compute the price indexes that correspond to the smaller amount of income required to purchase a unit quantity of the corresponding basket. For simplicity we use the U.S. currency as a numeraire. The consumer price index in region $i$, expressed in dollars $P_{C}^{i}$, is given by:

$$
P_{C}^{i}=\left[\gamma\left(P_{T}^{i}\right)^{1-\theta}+(1-\gamma)\left(P_{N}^{i}\right)^{1-\theta}\right]^{\frac{1}{1-\theta}}, \quad i=U, E, A,
$$

where $P_{T}^{i}$ is the price index of traded goods and $P_{N}^{i}$ is the price of non-traded goods in region $i$. The price indices of traded consumption in the three regions expressed in dollars, $P_{T}^{U}, P_{T}^{E}$, and $P_{T}^{A}$, are:

$$
\begin{aligned}
P_{T}^{U} & =\left[\alpha\left(P_{U}\right)^{1-\eta}+(\beta-\alpha)\left(P_{E}\right)^{1-\eta}+(1-\beta)\left(P_{A}\right)^{1-\eta}\right]^{\frac{1}{1-\eta}} \\
P_{T}^{E} & =\left[(\beta-\alpha)\left(P_{U}\right)^{1-\eta}+\alpha\left(P_{E}\right)^{1-\eta}+(1-\beta)\left(P_{A}\right)^{1-\eta}\right]^{\frac{1}{1-\eta}} \\
P_{T}^{A} & =\left[\frac{1-\delta}{2}\left(P_{U}\right)^{1-\eta}+\frac{1-\delta}{2}\left(P_{E}\right)^{1-\eta}+\delta\left(P_{A}\right)^{1-\eta}\right]^{\frac{1}{1-\eta}},
\end{aligned}
$$

where $P_{i}$ is the dollar price of the traded good produced in region $i$. Throughout the paper we assume that all prices are fully flexible. There are also no impediments to trade, so that the law of one price holds for each single traded good (i.e., the price of a given traded good is the same across the world, adjusted for the exchange rate).

The demands for the various goods in a given region are driven by the aggregate consumption in the region, as well as the various relative prices. The bilateral terms-of-trade $\tau_{i, j}$, are the price of 
the traded good produced in region $j$, relative to the price of the traded good produced in region $i$ :

$$
\tau_{U, A}=\frac{P_{A}}{P_{U}}, \quad \tau_{U, E}=\frac{P_{E}}{P_{U}}, \quad \tau_{E, A}=\frac{P_{A}}{P_{E}}=\frac{\tau_{U, A}}{\tau_{U, E}}
$$

An increase in $\tau_{U, E}$ is a deterioration of the U.S. terms-of-trade vis-à-vis Europe, as Europeanmade goods are now more expensive in terms of U.S.-produced goods. It can also interpreted as a competitiveness gain for the U.S. vis-à-vis Europe.

A key relative price in region $i$ is the price of the domestic non-traded goods, relative to the price of the traded basket in the region:

$$
x^{i}=P_{N}^{i} / P_{T}^{i}, \quad i=U, E, A
$$

An increase in $x^{i}$ indicates that, in region $i$, non-traded goods are more expensive in terms of the composite traded consumption basket.

The bilateral nominal exchange rates represent the value of a currency in terms of another, with $E_{i, j}$ being the amount of region $i$ 's currency that is required to purchase one unit of region j's currency. Throughout the paper we refer to the currencies of the U.S., Europe and Asia as the dollar, the euro, and the yen, respectively. The three bilateral nominal exchange rates in our setup are $E_{U, E}, E_{U, A}$, and $E_{E, A}$, with an increase in $E_{U, E}$ reflecting a nominal depreciation of the dollar against the euro. While nominal exchange rates indicate the relative values of currencies, they do not capture the level of consumer prices in the various regions. If a depreciation of the dollar against the euro is exactly offset by an increase in the consumer price index (5) in the U.S., then the ratio of U.S. and European consumer prices in a given currency is unchanged.

The real exchange rates (RER) represents the relative prices in terms of aggregate price indexes (5). The three bilateral real exchange rates in our setup are:

$$
q_{U, A}=\frac{P_{C}^{A}}{P_{C}^{U}}, \quad q_{U, E}=\frac{P_{C}^{E}}{P_{C}^{U}}, \quad q_{E, A}=\frac{P_{C}^{A}}{P_{C}^{E}}=\frac{q_{U, A}}{q_{U, E}}
$$


An increase in $q_{U, E}$ is an increase in the European consumer price index, relative to the U.S. Such an increase represents a real depreciation of the dollar against the euro, that is a depreciation of the U.S. currency that is not offset by movements in the local currency price index. Bilateral real exchange rates are driven by both the terms-of-trades and the relative prices of non-traded goods.

An effective measure of the external value of a currency by taking weighted averages of the various bilateral exchange rates:

$$
\begin{aligned}
& q^{U}=\left(q_{U, E}\right)^{\frac{\beta-\alpha}{1-\alpha}}\left(q_{U, A}\right)^{\frac{1-\beta}{1-\alpha}} \\
& q^{E}=\left(q_{U, E}\right)^{-1}\left(q_{U, A}\right)^{\frac{1-\beta}{1-\alpha}} \\
& q^{A}=\left(q_{U, A}\right)^{-1}\left(q_{U, E}\right)^{\frac{1}{2}}
\end{aligned}
$$

An increase in $q^{U}$ indicates that dollar depreciates in real effective terms, reflecting a depreciation against the euro (an increase in $q_{U, E}$ ) or the yen (an increase in $q_{U, A}$ ).

While real exchange rates are driven entirely by relative prices, namely the terms-of-trade and the relative prices of non-traded goods, the nominal exchange rates are also affected by the level of prices in particular regions. Solving for nominal exchange rates then requires a specification of monetary policy to determine the price levels. We follow Obstfeld and Rogoff (2005) and assume that central banks keep the price of a basket of domestically-produced goods constant in local currency. We focus our discussion on real exchange rates, as the movements in nominal exchange rates are very similar.

\subsection{International financial positions}

\subsubsection{Initial asset and liability positions}

A central feature of our analysis is the integration of financial markets, with each region holding substantial asset positions in the other two regions. We denote region $i$ 's foreign assets by $H^{i}$, 
and its liabilities by $L^{i}$, expressing all values in dollars without loss of generality. The difference represents the net international position of the region, which we denote by $F^{i}=H^{i}-L^{i}$.

Assets and liabilities in each region's balance sheet consists of assets denominated in different currencies. Exchange rate movements, then, affect their values and lead to capital gains and losses across the three regions. $H_{j}^{i}$ denotes region $i$ 's assets that are denominated in region $j$ 's currency. For instance, $H_{U}^{E}$ is the value of dollar-denominated assets held by European investors. Similarly, $L_{j}^{i}$ denotes region $i$ 's liabilities that are denominated in region $j$ 's currency. Following Obstfeld and Rogoff (2005) we consider that positions are in a high-return bond paying an interest rate $r^{W}$, except for the liabilities of the U.S. which are in a low-return dollar denominated bond paying an interest rate $r^{U}<r^{W}$. This feature captures the "exorbitant privilege" the U.S. enjoys in its ability to borrow from the rest world at lower rates than it faces when lending (see Gourinchas and Rey, 2006, and Lane and Milesi-Ferretti, 2006). Positions in the low-return bond are denoted by a tilde.

Table 1 illustrates the initial composition of international balance sheets in the three regions. The values are derived from those used by Obstfeld and Rogoff (2005). The top section of Table 1 shows the assets and liabilities of the U.S. The assets include positions in all currencies, and liabilities in the low return dollar denominated bond:

$$
H^{U}=H_{U}^{U}+H_{E}^{U}+H_{A}^{U}, \quad L^{U}=\tilde{L}_{U}^{U}
$$

The U.S. in a net debtor. A sizable share of U.S. assets (60 percent) is denominated in foreign currencies, while all U.S. liabilities are in dollar, in the low-return bond. This pattern is consistent with the U.S. numbers detailed in Tille (2005). The U.S. net position is then highly leveraged, with substantial asset positions in foreign currencies and large liabilities in dollar. The middle section of Table 1 shows the European balance sheet, with assets and liabilities in all currencies:

$$
H^{E}=\tilde{H}_{U}^{E}+H_{U}^{E}+H_{E}^{E}+H_{A}^{E}, \quad L^{E}=L_{U}^{E}+L_{E}^{E}+L_{A}^{E}
$$


The position of Europe is balanced with equal amounts of assets and liabilities. European assets are mostly denominated in euro and dollar (57 and 37 percent of the total, respectively), with the latter consisting mostly of low-return bonds invested in the U.S. Similarly, European liabilities are predominantly denominated in euro (80 percent), with the remainder in dollar. The bottom section of Table 1 shows the Asian balance sheet:

$$
H^{E}=\tilde{H}_{U}^{A}+H_{U}^{A}+H_{E}^{A}+H_{A}^{A}, \quad L^{A}=L_{U}^{A}+L_{E}^{A}+L_{A}^{A}
$$

Asia is a net creditor to the rest of the world, with the bulk (80 percent) of its assets consisting of dollar-denominated assets, essentially in low-return bonds invested in the U.S. The liability side is relatively evenly split across the three currencies. In net terms, Asia is substantially leveraged, with large assets in dollar and substantial liabilities in yen, and to a lesser extent in euro.

\subsubsection{Dynamics of balance sheets}

The value of each region's assets and liabilities fluctuates for three reasons. First, gross trade flows lead to the accumulation of additional assets and liabilities. Second, the existing positions generate a stream of interest payments. Third, exchange rate fluctuations affect the value of positions in different currencies.

Trade flows The first factor reflects gross trade flows. We denote the value, in dollar, of region $i$ 's exports to region $j$ by $G H_{j}^{i}$. For instance, $G H_{A}^{E}$ is the value of European exports to Asia. The mapping of trade flows into the dynamics of the balance sheet requires us to address two issues that are not present in simpler models, namely the relative magnitude of financial and trade flows, and the currency compositions.

In net terms, the trade balance maps into an equal change in the net foreign asset position, ceteris paribus. The linkage is looser when we consider gross flows however. Consider an example where a country $(A)$ exports 100 worth of goods to another country $(B)$ and imports 120 worth 
of goods. Country $A$ clearly runs a trade deficit of 20 , with a corresponding deterioration in its net foreign asset position. The picture in terms of gross flows is not as straightforward. A first possibility is that all gross exports lead to an accumulation of gross foreign assets, whereas all gross imports lead to an accumulation of foreign liabilities. The gross assets and liabilities of country $A$ then increase by 100 and 120 respectively. Another possibility is that the entire proceeds of exports are used to pay for imports, with an accumulation of liabilities amounting only to the trade deficit. The gross assets and liabilities of country $A$ then increase by 0 and 20 respectively. This simple example shows how a given situation in net terms can correspond to vastly different situations in gross terms.

Gross asset and liability positions play a central role in our analysis. Recall that U.S. assets include a substantial share of foreign currencies, while U.S. liabilities are in dollar. The magnitude of the valuation effect of an exchange rate movement then depends on the gross assets. As our analysis considers an adjustment over several periods, an exchange rate movement in the future will have a different impact depending on the extent to which gross assets increased, for a given path of the net asset position.

We rely on the empirical evidence on the relative magnitude of gross trade and financial flows, as economic theory does not provide us with an a-priori guess. Data for the U.S. are presented in Figure 3, where the solid line is the ratio between gross financial outflows and gross exports, while the dotted line is the ratio between gross financial inflows and gross imports. Both lines show similar positive trends, with gross financial flows increasing from 10-15 percent of trade flows in the early 1960's to 40-50 percent currently, a pattern that reflects the increase in financial integration. Based on this evidence, we assume that a fraction $\pi=0.5$ of trade flows map into corresponding financial flows. While tractable, this approach does not guarantee the internal consistency of the balance sheet in general. It does so however in the scenario we consider, as discussed below. 
In addition of the magnitude of gross financial flows, their currency composition affects the dynamics of our model. If for instance the U.S. accumulate assets in foreign currencies, future exchange rate movements will lead to a larger valuation effect than if the additional U.S. assets are in dollar. In terms of region $i$ 's exports to region $j, G H_{j}^{i}$, we assume that a share $\mu_{j, U}^{i}$ of these flows leads to the accumulation of assets denominated in dollar. Similarly, a share $\mu_{j, E}^{i}$ leads to the accumulation of assets denominated in euro, and a share $\mu_{j, A}^{i}=1-\mu_{j, U}^{i}-\mu_{j, E}^{i}$ leads to the accumulation of assets denominated in yen.

While we lack evidence on the currency composition of gross financial flows, to our knowledge, we take an educated guess relying on the available evidence on the invoicing of international trade flows, as reported by Goldberg and Tille $(2005),{ }^{2}$ who show a prominent role of the dollar in trade flows involving the U.S.. Our assumption is presented in Table 2. The top section of Table 2 shows the composition for U.S. exports, which lead mostly to the accumulation of dollar assets. We assume that half of the financial flows from exports to Europe leads the U.S. to accumulate assets in dollar, with the other half leading to the accumulation of assets in euro. Exports to Asia translate mostly into the accumulation of dollar-denominated assets (85 percent), with the residual being in yen-denominated assets. All accumulation of U.S. assets is in high-return bonds.

The middle section of Table 2 shows the situation for European exports. All exports to the U.S. lead to the accumulation of dollar-denominated assets, which we take to be in the low-return bond. Exports to Asia lead mostly to the accumulation of euro-denominated assets (50 percent), with also a substantial accumulation of dollar-denominated assets (35 percent) and a small accumulation of yen-denominated assets. We consider that all assets accumulated from exports to Asia consist of high-return bonds.

The bottom section of Table 2 corresponds to Asian exports. All exports to the U.S. lead to the

\footnotetext{
${ }^{2}$ While a flow can be invoiced in a currency and transacted in another, we posit that the invoicing currency is a good indicator of the transaction currency.
} 
accumulation of dollar-denominated assets, which we take to be in the low-return bond. Exports to Europe lead mostly to the accumulation of euro-denominated assets (80 percent), with the residual equally divided between dollar-denominated and yen-denominated assets. We assume that all assets accumulated from exports to Europe consist of high-return bonds.

Interest payments and valuation gains The second driver of changes in asset and liabilities is the flow of interest income. For simplicity, we assume that a share $\pi$ of the proceeds from interest payment are simply added to the principal of the corresponding position, with $\pi$ being the same as the share of gross trade flows that map into financial flows. The net interest income for each region is the difference between the interest earned on its assets and that paid on its liabilities. Based on the structure of the balance sheets presented above, we write net interest incomes for the three regions as:

$$
\begin{aligned}
& N I^{U}=r^{W} H^{U}-r^{U} L^{U} \\
& N I^{E}=r^{U} \tilde{H}_{U}^{E}+r^{W}\left(H_{U}^{E}+H_{E}^{E}+H_{A}^{E}\right)-r^{W} L^{E}, \\
& N I^{A}=r^{U} \tilde{H}_{U}^{A}+r^{W}\left(H_{U}^{A}+H_{E}^{A}+H_{A}^{A}\right)-r^{W} L^{A}=-N I^{U}-N I^{E},
\end{aligned}
$$

The final driver of balance sheet dynamics are the valuation effects stemming from exchange rates movements. As we express all positions in dollar, there is no such effect for the positions in dollar-denominated assets. However, the dollar value of positions in euro- or yen-denominated assets is affected. We denote by $V H_{j}^{i}$ the change in the value of region $i$ 's gross assets denominated in region $j$ 's currency due to exchange rate movements. $V L_{j}^{i}$ is defined similarly for liabilities. We again assume that a share $\pi$ of these valuations effects are added to the principal of the corresponding positions.

The valuation effects are driven by nominal exchange rates. Consider a period where the dollar- 
euro exchange rate changes from $E_{U, E 0}$ to $E_{U, E}$, while the dollar-yen exchange rate goes from $E_{U, A 0}$ to $E_{U, A}$. The valuation changes for U.S. assets denominated in euro and yen are:

$$
V H_{E}^{U}=\left(\frac{E_{U, E}}{E_{U, E 0}}-1\right) H_{E}^{U} \quad V H_{A}^{U}=\left(\frac{E_{U, A}}{E_{U, A 0}}-1\right) H_{A}^{U},
$$

The valuation effects for Europe and Asia are computed along similar lines.

Overall dynamics and consistency The dynamics of the various positions are given by combining the three channels detailed above. For instance, the U.S. assets and liabilities at the end of a period are given as follows, with a prime indicating values at the end of the period:

$$
\begin{aligned}
H_{U}^{U \prime} & =H_{U}^{U}+\pi\left[r^{W} H_{U}^{U}+\mu_{E, U}^{U} G H_{E}^{U}+\mu_{A, U}^{U} G H_{A}^{U}\right] \\
H_{E}^{U \prime} & =H_{E}^{U}+\pi\left[r^{W} H_{E}^{U}+\mu_{E, E}^{U} G H_{E}^{U}+\mu_{A, E}^{U} G H_{A}^{U}+V H_{E}^{U}\right] \\
H_{A}^{U \prime} & =H_{A}^{U}+\pi\left[r^{W} H_{A}^{U}+\left(1-\mu_{E, U}^{U}-\mu_{E, E}^{U}\right) G H_{E}^{U}+\left(1-\mu_{A, U}^{U}-\mu_{A, E}^{U}\right) G H_{A}^{U}+V H_{A}^{U}\right] \\
\tilde{L}^{U \prime} & =\tilde{L}^{U}+\pi\left[r^{U} \tilde{L}^{U}+\left(G H_{U}^{E}+G H_{U}^{A}\right)\right]
\end{aligned}
$$

The dynamics of the European and Asian balance sheets are computed along similar lines.

We now present the conditions under which our assumption that a share $\pi$ of trade flows, interest payments and valuation is added to the gross positions does not lead to inconsistencies, focusing on the U.S. for brevity. In net terms, the financial flows, $F F^{U}$, consist of two main components. The first is the proceeds of trade flows and net interest payments that are added to net assets (which are a share $\pi$ of these flows). The second is the share $(1-\pi)$ of valuation gains that is not added to the principal of the corresponding positions, bearing in mind that a valuation gain that is brought back in the U.S. is a capital inflow, i.e. a negative financial flow. The financial flows are then:

$$
\begin{aligned}
F F^{U} & =\pi\left[\left(G H_{E}^{U}+G H_{A}^{U}\right)-\left(G H_{U}^{E}+G H_{U}^{A}\right)+N I^{U}\right]-(1-\pi)\left(V H_{E}^{U}+V H_{A}^{U}\right) \\
& =\pi C A^{U}-(1-\pi)\left(V H_{E}^{U}+V H_{A}^{U}\right)
\end{aligned}
$$


where $C A^{U}$ is the U.S. current account, that is the overall net trade and interest payments flows. This relation shows that the net financial flows and current account are equal, as they should be, only when:

$$
F F^{U}=C A^{U}=\pi C A^{U}-(1-\pi)\left(V H_{E}^{U}+V H_{A}^{U}\right) \Rightarrow C A^{U}=-\left(V H_{E}^{U}+V H_{A}^{U}\right)
$$

Therefore, our assumption that $\pi$ is the same across the board is valid only when the current account is the inverse of the capital gains, that is when capital gains are associated with a current account deficit.

A complementary way to establish this point is to look at the dynamics of the net foreign asset position. In out setup, the change in the net foreign asset position is the sum of the proceeds of trade flows and net interest payments that are added to net assets, and the valuation gains that are added to the corresponding positions:

$$
F^{U \prime}-F^{U}=\pi C A^{U}+\pi\left(V H_{E}^{U}+V H_{A}^{U}\right)
$$

The changes in the net positions in the data, such as the one published by the BEA, combine the current account and the valuation affects:

$$
\left(F^{U \prime}-F^{U}\right)_{\mathrm{BEA}}=C A^{U}+\left(V H_{E}^{U}+V H_{A}^{U}\right)
$$

Comparing (19) and (20) clearly shows that the dynamics of net foreign assets are inconsistent in general. The notable exception to this problem is the case where net foreign assets are constant: $\left(F^{U \prime}-F^{U}\right)_{\mathrm{BEA}}=\left(F^{U \prime}-F^{U}\right)=0$. In this case, the trade flows, interest incomes and valuation effects sum to zero, be they all multiplied by $\pi$ or not. As our scenario analysis will focus on constant net asset positions, our scaling of gross flows and valuations by $\pi$ across the board is fine, though it would be problematic for other scenarios. In general, the shares $\pi$ would have to vary across the different components of the international accounts. While this would be relatively manageable in a two-country model, it becomes tedious in a three-country setup such as the one we consider. 
Aggregating the various components of balance sheet dynamics, the changes in the net foreign asset positions of the various countries are the sums of the current accounts and the valuation effects on assets and liabilities:

$$
\begin{aligned}
0 & =C A^{U}+\left(V H_{E}^{U}+V H_{A}^{U}\right) \\
0 & =C A^{E}+\left(V H_{E}^{E}+V H_{A}^{E}\right)-\left(V L_{E}^{E}+V L_{A}^{E}\right) \\
0 & =C A^{A}+\left(V H_{E}^{A}+V H_{A}^{A}\right)-\left(V L_{E}^{A}+V L_{A}^{A}\right)
\end{aligned}
$$

\subsection{Market-clearing conditions}

In each region, the current account, in dollars, is the sum of net interest income and the trade balance, the later being the difference between the value of tradable output and the value of consumption of tradable goods. For simplicity, the supply-side of the world economy is modeled as an endowment economy. We denote the endowments of tradable and non-traded goods in region $i$ by $Y_{T}^{i}$ and $Y_{N}^{i}$, respectively. Note that the valuation effects of exchange rate movements, $V H$ 's and $V L$ 's, do not enter the current account as they do not entail any financial flows across countries. The current accounts are written as:

$$
\begin{aligned}
C A^{U} & =N I^{U}+P_{U} Y_{T}^{U}-P_{T}^{U} C_{T}^{U} \\
C A^{E} & =N I^{E}+P_{E} Y_{T}^{E}-P_{T}^{E} C_{T}^{E}, \\
C A^{A} & =N I^{A}+P_{A} Y_{T}^{A}-P_{T}^{A} C_{T}^{A}=-\left(C A^{U}+C A^{E}\right) .
\end{aligned}
$$

The clearing of goods markets requires that the endowments of the various goods are equal to domestic and foreign consumptions, which depend on aggregate consumptions in the various regions and on relative prices. We define the following ratios between the various endowments of tradable 
and non-traded goods:

$$
\begin{aligned}
\sigma_{U / E} & =\frac{Y_{T}^{U}}{Y_{T}^{E}}, \quad \sigma_{U / A}=\frac{Y_{T}^{U}}{Y_{T}^{A}}, \\
\sigma_{N / U} & =\frac{Y_{N}^{U}}{Y_{T}^{U}}, \quad \sigma_{N / E}=\frac{Y_{N}^{E}}{Y_{T}^{E}}, \quad \sigma_{N / A}=\frac{Y_{N}^{A}}{Y_{T}^{A}} .
\end{aligned}
$$

We use lower-case variables to denote the ratio between a dollar value and the value of the endowment of U.S. tradable good, $P_{U} Y_{T}^{U}$. We scale the various trade flows in this way: $g h_{j}^{i}=G H_{j}^{i} /\left(P_{U} Y_{T}^{U}\right)$. Net interest incomes and current accounts are similarly scaled:

$$
n i^{U}=\frac{N I^{U}}{P_{U} Y_{T}^{U}}, \quad n i^{E}=\frac{N I^{E}}{P_{U} Y_{T}^{U}}, \quad c a^{U}=\frac{C A^{U}}{P_{U} Y_{T}^{U}}, \quad c a^{E}=\frac{C A^{E}}{P_{U} Y_{T}^{U}} .
$$

Using consumption demands, we can write the various trade flows in terms of relative prices (the terms-of-trade and price between traded and non-traded goods), and the trade balances (current account net of interest income). The resulting expression for U.S. exports as:

$$
\begin{aligned}
g h_{E}^{U} & =\frac{\beta-\alpha}{(\beta-\alpha)+\alpha\left(\tau_{U, E}\right)^{1-\eta}+(1-\beta)\left(\tau_{U, A}\right)^{1-\eta}}\left[\frac{\tau_{U, E}}{\sigma_{U / E}}+n i^{E}-c a^{E}\right] \\
g h_{A}^{U} & =\frac{1-\delta}{(1-\delta)+(1-\delta)\left(\tau_{U, E}\right)^{1-\eta}+2 \delta\left(\tau_{U, A}\right)^{1-\eta}}\left[\frac{\tau_{U, A}}{\sigma_{U / A}}-\left(n i^{U}+n i^{E}\right)+\left(c a^{U}+c a^{E}\right)\right] .
\end{aligned}
$$

The market-clearing condition for U.S. produced tradable goods combined the domestic demand for these goods along with the foreign demands (28)-(29) is:

$$
1=\frac{\alpha}{\alpha+(\beta-\alpha)\left(\tau_{U, E}\right)^{1-\eta}+(1-\beta)\left(\tau_{U, A}\right)^{1-\eta}}\left[1+n i^{U}-c a^{U}\right]+g h_{E}^{U}+g h_{A}^{U}
$$

Similar relations give the market-clearing condition for European and Asian tradable goods.

The market-clearing conditions for the U.S. non-traded goods are:

$$
\sigma_{N / U}=\frac{1-\gamma}{\gamma}\left[x^{U}\right]^{-\theta}\left[\alpha+(\beta-\alpha)\left(\tau_{U, E}\right)^{1-\eta}+(1-\beta)\left(\tau_{U, A}\right)^{1-\eta}\right]^{-\frac{1}{1-\eta}}\left[1+n i^{U}-c a^{U}\right]
$$

With similar conditions for European and Asian non-traded goods. 
A noteworthy feature of the market-clearing conditions (28)-(31) is that they do not involve the share $\pi$ linking trade flows and financial flows. Given the current accounts and net interest incomes $\left(c a^{U}, c a^{E}, n i^{U}, n i^{E}\right)$ we can compute the various terms-of-trade and traded-non-traded prices. $\pi$ matters only mapping the ensuing results into the dynamics of the various components of the international balance sheet.

Aggregate consumption in region $i$ can be inferred from its exogenous endowment of non-traded good, and the various relative prices, using the demand for non-traded good:

$$
C^{i}=\frac{1}{1-\gamma}\left[\frac{P_{N}^{i}}{P_{C}^{i}}\right]^{\theta} Y_{N}^{i}=\frac{1}{1-\gamma}\left[\gamma\left(x^{i}\right)^{\theta-1}+(1-\gamma)\right]^{-\frac{\theta}{1-\theta}} Y_{N}^{i}
$$

\subsection{Solution method}

Our method computes the various prices in a period based on the initial international balances sheets and structural parameters. The results are then mapped into the dynamics of the balance sheet to compute a new set of international assets and liabilities that underpin the solution for the following period.

Given an initial structure of assets and liabilities and initial nominal exchange rates, we can easily compute the net interest incomes (15)-(17). We then pick values for the U.S. and European current accounts in dollars, $C A^{U}$ and $C A^{E}$, and the endowment of U.S. tradable goods, $Y_{T}^{U}$. The current account values are not freely picked. For instance, when we aim for constant net asset positions, we iterate our procedure so the current accounts lead to constant positions. Similarly, the endowment of U.S. tradable goods is computed based on the current allocation (as in Obstfeld and Rogoff, 2005) and then held constant.

Armed with the values for the U.S. and European current accounts, the net interest incomes, and the endowment of U.S. tradable goods, $Y_{T}^{U}$, we compute the terms-of-trade $\tau_{U, A}$ and $\tau_{U, E}$, the relative prices of non-traded goods, $x^{U}, x^{E}$, and $x^{A}$, and the price of the U.S. tradable good, 
$P_{U}$. This is done by numerically solving a system including the market-clearing conditions, and the expression for price of the U.S. tradable good. Having solved the various relative prices, the real and nominal exchange rates easily follow. Combining the nominal exchange rates with the ones taken from the previous period, we compute the valuations effects on assets and liabilities. Combining the trade flows, interest income and valuation effects, we compute the dynamics of the balance sheets, using the scaling factor $\pi$. These new asset and liabilities positions serve as the basis for the solution in the following period.

Note that the dynamic dimension of our analysis comes solely through the dynamics of the international balance sheets. For instance, consumption is not computed from an intertemporal optimization, but is given by the exogenous endowments and the current account, the later being set by our assumption of the dynamics of net foreign assets.

\section{Global adjustment under various scenarios}

\subsection{Static scenarios}

The choose parameter values that are presented in Table 3 . We take the same values as in Obstfeld and Rogoff (2005), and refer the reader to their contribution for a detailed discussion. Column (b) of Table 3 shows our baseline choice, with column (c) showing alternative values considered in extensions. We assume that half the gross trade flows map into financial flows $(\pi=0.5)$ as is the case in the U.S. currently (Figure 3). We consider two extensions: one with no accumulation of assets and liabilities beyond the current positions $(\pi=0)$, and one where the interest rate on U.S. liabilities increases to match the world interest rate.

We start by briefly reviewing the results of Obstfeld and Rogoff (2005). They consider static scenarios in the sense that the current accounts in all countries return to zero immediately. ${ }^{3}$ Column

\footnotetext{
${ }^{3}$ Obstfeld and Rogoff (2005) do not present their scenario as the adjustment taking place in one period, but rather in terms of comparing the current situation with a steady state where net positions are constant. However, as they abstract from any dynamics, their scenarios implicitly assumes an immediate adjustment.
} 
(a) of Table 4 shows the main results for their analysis. The top section indicates the real depreciation of the dollar against the other currencies, while the middle section shows the effective real depreciations of the various currencies (the movements in nominal exchange rates are very similar). The bottom section shows the changes in aggregate consumption in all regions. ${ }^{4}$

Column (a) in Table 4 shows a scenario that entirely abstract from any valuation effect, that is, a scenario where all assets and liabilities are denominated in dollar. The global rebalancing of the world economy requires a sharp depreciation of the dollar of 38 percent in effective terms, mirrored principally by a substantial yen appreciation. The adjustment entails a 5.6 percent contraction in U.S. consumption, with expansions abroad, especially in Asia. Obstfeld and Rogoff (2005) also consider valuation effects, a case presented in column (b) of Table 4. Their exact scenario still requires all current accounts to move to zero. The adjustment entails a substantial depreciation of the dollar. This, in turn, generates a substantial capital gain for the U.S., as a large share of its assets is denominated in foreign currencies. In other words, Obstfeld and Rogoff (2005) use the capital gain of the U.S. to pay down a substantial amount of the foreign debt. Table 5 shows the net asset positions of all regions, expressed in percent of the value of U.S. traded output. The first row is the initial situation, while the second row shows the scenario considered by Obstfeld and Rogoff (2005). The table shows a very large valuation gain that allows the U.S. to cut its net debt by 70 percent, mostly at the expense of Asia. As the depreciation of the dollar substantially improves the U.S. balance sheet, the net interest payments of the U.S. to the rest of the world are also improved. With the current account being the sum of these payments and the trade balance, the improvement in net interest payments reduces the magnitude of the improvement in the trade balance that is required to bring the current account to zero. This, in turn, reduces the required movement in the exchange rate, as shown in column (b) of Table 4. Obstfeld and Rogoff (2005)

\footnotetext{
${ }^{4}$ The numbers in Table 4 slightly differ form the ones presented in Obstfeld and Rogoff (2005) as we consider a structure of assets and liabilities in Table 1 that is slightly different from the one they use.
} 
argue that the benefits from the valuation effect are secondary, as the dollar still has to depreciate by 33 percent.

\subsection{A dynamic scenario}

\subsubsection{Stabilization of net investment positions}

The limited impact of the valuation effect on the exchange rate in Obstfeld and Rogoff (2005) is a consequence of using the valuation gain to reduce the U.S. net debt, while still requiring an immediate adjustment in the current account. This is only one of several possible use of the valuation gains, and our analysis focuses on an alternative use. Specifically, we consider a scenario where net international investment positions are held constant in all three regions. We regard this scenario as a reasonable alternative, as the U.S. net external debt has remained essentially unchanged in the last three years (Figure 1) at a level that has so far proved manageable. In our scenario, the valuation effects stemming from exchange rate movements allow the various regions to run current account surpluses and deficits. These imbalances are financed by valuation gains and losses, keeping international investment positions constant, as shown in equations (21)-(23).

Our scenario highlights two dimensions of adjustment, namely the ultimate movements in the various variable and the pace of adjustment. Equation (18) shows that valuation effects require movements in nominal exchange rate. In the long run, once adjustment has run its course, the economy reaches a new steady state where all variables are constant, including nominal ones as we assume that the central banks stabilize prices. There is therefore no ongoing valuation in the long run, and equations (21)-(23) show that the current accounts are in balance. While our scenario still requires an ultimate balancing of current accounts, it can accommodate a gradual adjustment. This dimension is relevant in assessing whether the re-balancing of imbalances can be disruptive, as a sizable depreciation of the dollar is likely to be more benign if spread through several years than if occurring in a short span. 


\subsubsection{Pace of adjustment}

The key feature of our alternative scenario is that the adjustment takes place at a much smoother pace than under the static scenarios. Figure 4 shows the path of the various current accounts, expressed as percentage of the value of U.S. traded output. All current accounts eventually go to zero, as the economy is then in a new steady state. The adjustment is quite gradual and spread over several periods (years). For instance, the U.S. current account deficit is only halved in the first three years.

The smooth pattern of adjustment is also observed for exchange rates. Figure 5 shows the paths of bilateral and effective real exchange rates, expressed in percentage changes from the initial levels. The dashed lines indicate the adjustment in the static scenario with valuation effect (column b of Table 4), while the solid lines show the adjustments under the dynamic scenario. The depreciation of the dollar clearly takes place at a gradual pace, both against the euro (panel A), the yen (panel B) and in trade-weighted terms. For instance, the dollar depreciates by 8.6 percent in the first year (in trade-weighted), and 15 percent by the second year. A similar pattern of gradual adjustment is observed for the (moderate) appreciation of the euro and the (substantial) appreciation of the yen.

Intuitively, the gradual nature of the adjustment reflects the use of valuation gains to finance international imbalances. The depreciation of the dollar leads to a sizable capital gain for the U.S., which uses the proceed to finance a trade deficit. While this mechanism can operate only temporarily, as valuation gains eventually go to zero, it allows for a gradual decline in trade gaps. In the first year, the 8.6 percent depreciation of the dollar allows the U.S. to finance a current account deficit of 15.7 percent of its tradable output, which represents a narrowing by only 4.3 percentage points from the initial deficit. The 6.4 percent depreciation in the second year generates a smaller capital gain, with the current account deficit narrowing an additional 3.6 percentage points to 12.1 percent of U.S. tradable output. This pattern is repeated period after period, with the exchange rate 
ultimately stabilizing and the current account returning into balance. Throughout the adjustment, the net positions of all regions has remained unchanged, as shown in the last row of Table $5 .^{5}$

\subsubsection{Magnitude of adjustment}

In addition to the gradual nature of the adjustment, our dynamic scenario allows for a moderate reduction in its ultimate magnitude. Column (c) of Table 4 shows the magnitude of depreciation in our dynamic scenario after 10 periods. While the dollar still substantially depreciates, the magnitude is reduced to 31.4 percent. The last two columns of Table 4 compare the long-run effect in the dynamic scenario to the changes in the static scenarios, with and without valuation effects. The depreciation of the dollar is reduced by nearly one-fifth compared to the static scenario that ignores valuation effects. This magnitude is consistent with the results in Gourinchas and Rey (2005) who find that valuation effects stemming from exchange rate movements accounts for one-third of the historical adjustment of U.S. external imbalances. Using a richer multi-country model, Helbling, Batini and Cardarelli (2005) argue that higher financial integration facilitates the process of current account adjustment. Comparing our dynamic scenario to the static case including valuation effects shows a moderate dampening, with the depreciation of the dollar being reduced by 4 percent in effective terms.

\subsubsection{The impact on international balance sheets}

The pacing of adjustment over several years in our scenario implies that the movements in international balance sheets over the period are not negligible. This is illustrated by the cumulative valuation gains in the three regions, shown in Figure 6. The thick solid line represents the cumulative gain for the U.S., with the thin dotted and solid lines showing the mirroring losses in Europe and Asia. The substantial depreciation of the dollar results in a large capital gain for the U.S., amounting

\footnotetext{
${ }^{5}$ Table 5 shows a moderate narrowing of the positions when scaled by U.S. tradable output. This is because we hold the net position unchanged in dollar. An increase in the price of the U.S. made tradable good, $P^{U}$, raises the value of the U.S. tradable output, thereby reducing the scaled positions.
} 
to $\$ 1.8$ trillion. This comes essentially at the expense of Asia, which suffers a loss of $\$ 1.4$ trillion, while Europe faces a moderate capital loss. The high exposure of Asia to capital loss is consistent with the findings of Higgins and Klitgaard (2004).

The combination of trade flows, interest income and valuation effects leads to substantial movements in international balance sheets. Table 6 shows the positions for all regions in the initial situation and in the long run (defined as 10 years after the adjustment started). The table indicates both the total positions and the sum of euro and yen positions, as only the latter are relevant for valuation effects. Under our assumption that one half of trade flows, interest income and valuation effects are mapped into asset and liability positions, we find that the gross positions nearly double over 10 years. As the net positions are by construction held unchanged, this represents a sizable increase in leverage, but is consistent with empirical evidence. Between 1994 and 2004 U.S. gross assets nearly doubled from 47 percent to 85 percent of GDP, while liabilities increased even more from 49 percent to 107 percent (Figure 7). The balance sheet dynamics stemming from our parametrization are therefore realistic.

The increase in gross positions, especially in euro and yen, explain the dampening of the ultimate adjustment described above. A given exchange rate movement taking place in the future generates a valuation effect that is larger than one generated by the same movement taking place in the early on, as it applies to larger positions.

\subsection{Sensitivity analysis}

\subsubsection{Alternative scenarios}

We complete our baseline scenario by considering two extensions. In the first we assume that all gross financial flows are netted out $(\pi=0)$, so gross assets and liabilities are held constant at their initial levels. This alternative with no gross financial flows illustrates the influence of the increase of

gross positions on our results. In the second extension we assume that the U.S. exorbitant privilege 
disappears, with the interest rate on the low-return dollar bonds, $r^{U}$, immediately increasing to the world interest rate, $r^{W}$ (this scenario holds $\pi$ at 0.5 ). The alternative with convergence of interest rates allows us to weight the gains from valuation effects against the interest burden of the U.S. net debt.

\subsubsection{Pace and magnitude of adjustment}

The gradual pace of adjustment is robust to the extension. The top panel of Figure 8 shows the path of the U.S. current account (scaled by the value of U.S. traded output) under the baseline adjustment (thick line), the alternative with no gross financial flows (dotted line) and the alternative with convergence of interest rates (dash-and-dot line). Figures 9 and 10 are identical for Europe and Asia, respectively. The gradual nature of adjustment is observed across all scenarios. Adjustment is slower under interest rate convergence, but the gap is small and entirely reflects the jump in interest rate in the first period. The pace of exchange rate adjustment (not shown for brevity) also remains gradual.

The ultimate magnitude of adjustment (after 10 years) is sensitive to the extensions. Column (a) of Table 7 corresponds to column (c) of Table 4 and shows the exchange rate and consumption movements in our baseline scenario. Column (b) shows the same numbers under the alternative with no gross financial flows. The magnitude of adjustment is substantially increased, with the dollar depreciating by 36 percent in effective terms, an increase by one-sixth compared to the baseline scenario.

The magnitude of ultimate adjustment is also sensitive to interest rates, with exchange rate movements being larger under the alternative of convergence (column c). The dollar now depreciates by 41 percent in effective terms, a one-third increase compared to the baseline scenario. The sensitivity to interest rate goes beyond the impact computed by Obstfeld and Rogoff (2005) who find that a convergence moderately increases the depreciation of the dollar vis-á-vis the euro (from 
28.6 to 30.1 percent). This difference reflects two aspects. First, Obstfeld and Rogoff (2005) assume that the convergence applies only to U.S. debt in short-duration bonds, which represents only 30 percent of U.S. liabilities. Second, our assumption that gross positions increase $(\pi>0)$ implies an increasing and costly leverage for the U.S. This dimension is substantial, as the gross positions double under the alternative scenario, as shown in Table 8 (the increase in positions is slightly larger than under our baseline scenario).

\subsubsection{The composition of adjustment}

While the adjustment of the current account shows little difference across our baseline scenario and the two alternatives we consider, the components of the current account are more contrasted. Table 9 summarizes the overall adjustment over the 10 periods we consider. The top section indicates the cumulative valuation gains for the three regions. Under the baseline adjustment (column a), the depreciation of the dollar leads to a $\$ 1.8$ trillion capital gain for the U.S., allowing it finance a gradual rebalancing of the current account. The U.S. gain is mirrored primarily by a loss in Asia. The valuation effect is essentially unchanged in the absence of gross flows (column b, with the differences from the baseline scenario given in column d). In the alternative with a convergence in interest rates, the valuation effects are magnified, with the U.S. gaining an additional $\$ 0.7$ trillion, owing to the larger depreciation of the dollar.

The valuation gains and losses exactly correspond to the cumulative current account under our assumption that net asset positions are constant. The cumulative current accounts are in turn the sum of net interest income and the trade balance, which are presented in the last two sections of Table 9. Under the baseline scenario, the U.S. benefits from net interest income, despite being a net debtor, as earns a larger return on its assets than it pays on its liabilities. This interest transfer comes essentially at the expense of Europe, while the net assets of Asia are large enough to offset its earning a lower rate on its assets than it pays on its liabilities. As a result of this "exorbitant 
privilege" the U.S. can run a cumulative trade deficit (\$2.2 trillion) that exceeds its cumulative current account deficit ( $\$ 1.8$ trillion). This limits the pressure on the exchange rate, which is driven primarily by the required adjustment in the trade balance.

While the cumulative current accounts are essentially the same in the alternative with no financial flows, they are more driven by trade balances. The U.S. earns no net interest income, so the rebalancing requires a smaller trade deficit ( $\$ 1.8$ trillion) than under the baseline scenario $(\$ 2.2$ trillion). In the absence of gross flows, the U.S. cannot increase its leverage between high return assets and low return liabilities, which limits its interest income. As more of the adjustment comes through the trade balance, the dollar depreciates more under this alternative.

While the U.S. runs a larger cumulative current account deficit in the alternative with interest rate convergence ( $\$ 2.5$ trillion) than in the baseline ( $\$ 1.8$ trillion), this is merely a reflection of the large movement of the exchange rate due to the interest burden of U.S. liabilities. The increase in the interest rate that the U.S. pays on this liabilities removes its "exorbitant privilege", and the net debt translates into substantial net interest payments. Compared to the baseline scenario, the U.S. pays $\$ 1.4$ trillion in net interest. This represents a $\$ 1.8$ trillion shift from the baseline scenario where the U.S. was receiving a net interest income of $\$ 0.4$ trillion. While the U.S. benefits from a larger valuation gain ( $\$ 2.5$ trillion, compared to $\$ 1.8$ trillion in the baseline), the extra gain is too small to offset the surge in the interest burden. The burden then requires a faster narrowing of the trade deficit, with the cumulative trade deficit amounting to $\$ 1.2$ trillion, i.e., half its value under the baseline case. The faster narrowing in the trade deficit requires a larger depreciation of the dollar. Note that the presence of valuation effects still smooths the adjustment. With the valuation effect, the difference in the trade balance from the baseline scenario ( $\$ 1.0$ trillion) amounts to 60 percent of the additional interest payments ( $\$ 1.8$ trillion), while in the absence of these effects the trade balance would have to exactly match the additional interest payments. The sensitivity of U.S. 
external accounts to alternative scenarios for the returns on assets and liabilities is in line with the results of Higgins, Klitgaard and Tille (2005).

The various scenarios are contrasted in Figure 8 which shows the paths of the U.S. current accounts, net interest income and trade balance (as percentage of the value of U.S. traded output) under the three scenarios. While the current account is broadly similar, the U.S. faces a higher net interest burden in the two alternative scenarios (especially under interest rate convergence), requiring a faster narrowing of the trade balance. Figures 9 and 10 show how the situation is mirrored in Europe and Asia respectively.

\section{Concluding remarks}

The rapidly widening U.S. current account deficit has received a lot of attention, with several economists pointing that bringing the current account down to a more sustainable level could require a substantial, and possibly disruptive, depreciation of the dollar. This paper assesses how such an adjustment is affected by the high degree of financial integration across countries. The main consequence of financial integration is the growing relevance of valuation effects, where exchange rate movements leads to sizable changes in the value of a country's assets and liabilities. We consider an adjustment scenario where current account imbalances are resorbed, and the net asset positions of the various countries are kept constant.

Our main finding is that high financial integration can potentially generate a "smooth landing" pattern with a very gradual movement of the current accounts into balance. Focusing on the U.S. in our model, the depreciation of the dollar generates capital gains, which can be used to finance a narrowing current account deficit while keeping the net debt vis-à-vis the rest of the world unchanged. The pace of adjustment is an important feature of a rebalancing scenario. One of the main concerns expressed for the unwinding of the current imbalances is that the adjustment may prove sudden and disorderly, with foreign investors loosing confidence in the U.S. for instance. 
Obstfeld and Rogoff (2005) stress the risk of a "hard landing," where the depreciation of the dollar that they calculate would take place in a fast and disruptive manner. While a 30 percent depreciation of the dollar in a single year could be disruptive for world markets, these would be in a better position to handle a similar movement when it is spread over several years. Our scenario finds that the largest one-year depreciation of the dollar is less than 10 percent, a magnitude that can be absorbed by markets: in 2003 and 2004 the dollar depreciated by 12.2 and 8.2 percent (as measured by the major currency index published by the Board of Governors), ${ }^{6}$ a movement that proved manageable.

A sensitivity analysis shows that the gradual pace adjustment, which is the central result of our analysis, remains robust to alternative scenarios. The magnitude of the exchange rate movements is however larger if we limit gross financial flows, thereby limiting the leverage between assets and liabilities with different rates of return. The U.S. also benefits from earning a larger return on its assets than it pays on its liabilities, and removing this spread leads to a larger adjustment in the exchange rate.

A caveat to our setup is that the dynamic linkages remain quite simple, as we do not consider any intertemporal optimization by agents. Richer models of the world economy, such as Blanchard et al. (2005), Helbling et al. (2005), and Faruqee et al. (2006) nevertheless also find a gradual adjustment.

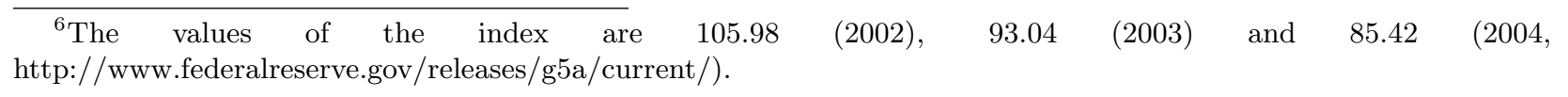




\section{References}

[1] Backus, D., Henriksen, E., Lambert, F., Telmer, C., 2005. Current account fact and fiction. Mimeo, New York University.

[2] Blanchard, O., Giavazzi, F., Sa, F., 2005. International investors, the U.S. current account and the dollar. Brookings Papers on Economic Activity, 1:2005, 1-49.

[3] Caballero, R., Fahri, E., Gourinchas, P.O., 2005. An equilibrium model of "global imbalances" and low interest rates. Mimeo, MIT and University of California, Berkeley.

[4] Clarida, R.H. (Ed.), 2006. G7 Current Account Imbalances: Sustainability and Adjustment. University of Chicago Press, Chicago, forthcoming.

[5] Dooley, M.P., Folkerts-Landau, D., Garber, P.M., 2005. Saving gluts and interest rates: The missing link to Europe. NBER Working Paper no. 11520.

[6] Dooley, M.P., Folkerts-Landau, D., Garber, P.M., 2006. Direct investment, rising real wages and the absorption of excess labor in the periphery. In: Clarida, R.H. (Ed.), G-7 Current Account Imbalances: Sustainability and Adjustment. University of Chicago Press, Chicago, forthcoming.

[7] Engel, C., Rogers, J., 2006. The U.S. current account deficit and the expected share of world output. NBER Working Paper no. 11921.

[8] Faruqee, H., Laxton, D., Muir, D., Pesenti, P., 2006. Smooth landing or crash? Model-based scenarios of global current account rebalancing. In: Clarida, R.H. (Ed.), G-7 Current Account Imbalances: Sustainability and Adjustment. University of Chicago Press, Chicago, forthcoming.

[9] Goldberg, L., Tille, C., 2005. Vehicle currency use in international trade. Federal Reserve Bank of New York Staff Report no. 200.

[10] Gourinchas, P.O., Rey, H., 2005. International financial adjustment. NBER Working Paper no. 11155.

[11] Gourinchas, P.O., Rey, H., 2006. From world banker to world venture capitalist: U.S. external adjustment and the exorbitant privilege. In: Clarida, R.H. (Ed.), G-7 Current Account Imbalances: Sustainability and Adjustment. University of Chicago Press, Chicago, forthcoming. 
[12] Helbling, T., Batini, N., Cardarelli, R., 2005. Globalization and external imbalances. In: IMF World Economic Outlook (April 2005). International Monetary Fund, Washington, DC, pp.109156.

[13] Higgins, M., Klitgaard, T., 2004. Reserve accumulation: Implications for global capital flows and financial markets. Current Issues in Economics and Finance 10, no. 10, Federal Reserve Bank of New York.

[14] Higgins, M., Klitgaard, T., Tille, C., 2005. The income implications of rising U.S. international liabilities. Current Issues in Economics and Finance 11, no. 12, Federal Reserve Bank of New York.

[15] Lane, P.R., Milesi-Ferretti, G.M., 2003. International financial integration. IMF Staff Papers $50,82-113$.

[16] Lane, P.R., Milesi-Ferretti, G.M., 2005. Financial globalization and exchange rates. IMF Working Paper no. 05/3.

[17] Lane, P.R., Milesi-Ferretti, G.M., 2006. A global perspective on external positions In: Clarida, R.H. (Ed.), G-7 Current Account Imbalances: Sustainability and Adjustment. University of Chicago Press, Chicago, forthcoming.

[18] Obstfeld, M., 2004. External adjustment. Review of World Economics 140, 541-568.

[19] Obstfeld, M., Rogoff, K.S., 2005. Global current account imbalances and exchange rate adjustment. Brookings Papers on Economic Activity, 1:2005, 67-123.

[20] Obstfeld, M., Rogoff, K.S., 2006. The unsustainable U.S. current account position revisited. In: Clarida, R.H. (Ed.), G-7 Current Account Imbalances: Sustainability and Adjustment. University of Chicago Press, Chicago, forthcoming.

[21] Roubini, N., Setser, B., 2005, The sustainability of the U.S. external imbalances. Mimeo, New York University.

[22] Tille, C., 2003. The impact of exchange rate movements on U.S. foreign debt. Current Issues in Economics and Finance 9, no. 1, Federal Reserve Bank of New York.

[23] Tille, C., 2005. Financial integration and the wealth effect of exchange rate fluctuations. Federal Reserve Bank of New York Staff Report no. 226. 


\section{Appendix}

\section{A.1. Consumption allocation}

The allocation of consumption between traded and non-traded goods in region $i$ is:

$$
C_{T}^{i}=\gamma\left[\frac{P_{T}^{i}}{P_{C}^{i}}\right]^{-\theta} C^{i} \quad C_{N}^{i}=(1-\gamma)\left[\frac{P_{N}^{i}}{P_{C}^{i}}\right]^{-\theta} C^{i}
$$

The allocation of the consumption of traded goods in the three regions is given by:

$$
\begin{aligned}
C_{U}^{U} & =\alpha\left[\frac{P_{U}}{P_{T}^{U}}\right]^{-\eta} C_{T}^{U} \quad C_{E}^{U}=(\beta-\alpha)\left[\frac{P_{E}}{P_{T}^{U}}\right]^{-\eta} C_{T}^{U} \quad C_{A}^{U}=(1-\beta)\left[\frac{P_{A}}{P_{T}^{U}}\right]^{-\eta} C_{T}^{U} \\
C_{U}^{E} & =(\beta-\alpha)\left[\frac{P_{U}}{P_{T}^{E}}\right]^{-\eta} C_{T}^{E} \quad C_{E}^{E}=\alpha\left[\frac{P_{E}}{P_{T}^{E}}\right]^{-\eta} C_{T}^{E} \quad C_{A}^{E}=(1-\beta)\left[\frac{P_{A}}{P_{T}^{E}}\right]^{-\eta} C_{T}^{E} \\
C_{U}^{A} & =\frac{1-\delta}{2}\left[\frac{P_{U}}{P_{T}^{A}}\right]^{-\eta} C_{T}^{A} \quad C_{E}^{A}=\frac{1-\delta}{2}\left[\frac{P_{E}}{P_{T}^{A}}\right]^{-\eta} C_{T}^{A} \quad C_{A}^{A}=\delta\left[\frac{P_{A}}{P_{T}^{A}}\right]^{-\eta} C_{T}^{A}
\end{aligned}
$$

\section{A.2. Real and nominal exchange rates}

The bilateral real exchange rates are driven by both the terms-of-trades and the relative prices of non-traded goods, and are written as:

$$
\begin{aligned}
q_{U, E}= & \frac{\left[\alpha \tau_{U, E}^{1-\eta}+(\beta-\alpha)+(1-\beta) \tau_{U, A}^{1-\eta}\right]^{\frac{1}{1-\eta}}}{\left[\alpha+(\beta-\alpha) \tau_{U, E}^{1-\eta}+(1-\beta) \tau_{U, A}^{1-\eta}\right]^{\frac{1}{1-\eta}}} \frac{\left[\gamma+(1-\gamma)\left(x^{E}\right)^{1-\theta}\right]^{\frac{1}{1-\theta}}}{\left.[\gamma+\gamma)\left(x^{U}\right)^{1-\theta}\right]^{\frac{1}{1-\theta}}}, \\
q_{U, A}= & \frac{\left[\delta \tau_{U, A}^{1-\eta}+\frac{1-\delta}{2}+\frac{1-\delta}{2} \tau_{U, E}^{1-\eta}\right]^{\frac{1}{1-\eta}}}{\left[\alpha+(\beta-\alpha) \tau_{U, E}^{1-\eta}+(1-\beta) \tau_{U, A}^{1-\eta}\right]^{\frac{1}{1-\eta}}} \frac{\left[\gamma^{1-\theta}+(1-\gamma)\left(x^{A}\right)^{1-\theta}\right]^{\frac{1}{1-\theta}}}{\left[\gamma+(1-\gamma)\left(x^{U}\right)^{1-\theta}\right]^{\frac{1}{1-\theta}}} \\
q_{E, A}= & \frac{q_{U, A}}{q_{U, E}}
\end{aligned}
$$

Turning to nominal exchange rates, we assume that central banks keep the price of a basket of domestically-produced goods constant in local currency:

$$
\begin{aligned}
& {\left[\gamma\left(P_{U}\right)^{1-\theta}+(1-\gamma)\left(P_{N}^{U}\right)^{1-\theta}\right]^{\frac{1}{1-\theta}}=1 \Rightarrow\left[\gamma+(1-\gamma)\left(\frac{P_{N}^{U}}{P_{T}^{U}} \frac{P_{T}^{U}}{P_{U}}\right)^{1-\theta}\right]\left(P_{U}\right)^{1-\theta}=1} \\
& {\left[\gamma\left(P_{E}^{*}\right)^{1-\theta}+(1-\gamma)\left(P_{N}^{E *}\right)^{1-\theta}\right]^{\frac{1}{1-\theta}}=1 \Rightarrow\left[\gamma+(1-\gamma)\left(\frac{P_{N}^{E *}}{P_{T}^{E *}} \frac{P_{T}^{E *}}{P_{E}^{*}}\right)^{1-\theta}\right]\left(P_{E}^{*}\right)^{1-\theta}=1} \\
& {\left[\gamma\left(P_{A}^{*}\right)^{1-\theta}+(1-\gamma)\left(P_{N}^{A *}\right)^{1-\theta}\right]^{\frac{1}{1-\theta}}=1 \Rightarrow\left[\gamma+(1-\gamma)\left(\frac{P_{N}^{A *}}{P_{T}^{A *}} \frac{P_{T}^{A *}}{P_{A}^{*}}\right)^{1-\theta}\right]\left(P_{A}^{*}\right)^{1-\theta}=1}
\end{aligned}
$$


Relative prices are not affected by the currency in which we express them. Given the relative price of non-traded goods, and the terms-of-trade, we derive the price of the three tradable goods, $P_{U}$, $P_{E}^{*}$ and $P_{A}^{*}$ :

$$
\begin{aligned}
& P_{U}=\left[\gamma+(1-\gamma)\left(x^{U}\right)^{1-\theta}\left[\alpha+(\beta-\alpha)\left(\tau_{U, E}\right)^{1-\eta}+(1-\beta)\left(\tau_{U, A}\right)^{1-\eta}\right]^{\frac{1-\theta}{1-\eta}}\right]^{-\frac{1}{1-\theta}} \\
& P_{E}^{*}=\left[\gamma+(1-\gamma)\left(x^{E}\right)^{1-\theta}\left[(\beta-\alpha)\left(\tau_{U, E}\right)^{-(1-\eta)}+\alpha+(1-\beta)\left(\tau_{U, A}\right)^{1-\eta}\left(\tau_{U, E}\right)^{-(1-\eta)}\right]^{\frac{1-\theta}{1-\eta}}\right]^{-\frac{1}{1-\theta}} \\
& P_{A}^{*}=\left[\gamma+(1-\gamma)\left(x^{A}\right)^{1-\theta}\left[\frac{1-\delta}{2}\left(\tau_{U, A}\right)^{-(1-\eta)}+\frac{1-\delta}{2}\left(\tau_{U, E}\right)^{1-\eta}\left(\tau_{U, A}\right)^{-(1-\eta)}+\delta\right]^{\frac{1-\theta}{1-\eta}}\right]^{-\frac{1}{1-\theta}}
\end{aligned}
$$

We solve the exchange rate by using the fact that the law of one price holds at the level of particular traded goods:

$$
\tau_{U, E}=\frac{E_{U, E} P_{E}^{*}}{P_{U}} \quad \tau_{U, A}=\frac{E_{U, A} P_{A}^{*}}{P_{U}}
$$

We then get the exchange rates:

$$
\begin{aligned}
E_{U, E} & =\tau_{U, E} \frac{P_{U}}{P_{E}^{*}} \\
& =\left[\frac{\gamma+(1-\gamma)\left(x^{U}\right)^{1-\theta}\left[\alpha+(\beta-\alpha)\left(\tau_{U, E}\right)^{1-\eta}+(1-\beta)\left(\tau_{U, A}\right)^{1-\eta}\right]^{\frac{1-\theta}{1-\eta}}}{\gamma\left(\tau_{U, E}\right)^{1-\theta}+(1-\gamma)\left(x^{E}\right)^{1-\theta}\left[(\beta-\alpha)+\alpha\left(\tau_{U, E}\right)^{1-\eta}+(1-\beta)\left(\tau_{U, A}\right)^{1-\eta}\right]^{\frac{1-\theta}{1-\eta}}}\right]^{-\frac{1}{1-\theta}} \\
E_{U, A}= & \tau_{U, A} \frac{P_{U}}{P_{A}^{*}} \\
= & {\left[\frac{\gamma+(1-\gamma)\left(x^{U}\right)^{1-\theta}\left[\alpha+(\beta-\alpha)\left(\tau_{U, E}\right)^{1-\eta}+(1-\beta)\left(\tau_{U, A}\right)^{1-\eta}\right]^{\frac{1-\theta}{1-\eta}}}{\gamma\left(\tau_{U, A}\right)^{1-\theta}+(1-\gamma)\left(x^{A}\right)^{1-\theta}\left[\frac{1-\delta}{2}+\frac{1-\delta}{2}\left(\tau_{U, E}\right)^{1-\eta}+\delta\left(\tau_{U, A}\right)^{1-\eta}\right]^{\frac{1-\theta}{1-\eta}}}\right]^{\frac{1}{1-\theta}} } \\
E_{E, A}= & E_{U, A} / E_{U, E}
\end{aligned}
$$

\section{A.3. Dynamics of the balance sheet}

$V H_{j}^{i}$ denotes the change in the value of region $i$ 's gross assets denominated in region $j$ 's currency due to exchange rate movements. $V L_{j}^{i}$ is defined similarly for liabilities. The valuation changes for U.S. assets denominated in euro and yen are:

$$
V H_{E}^{U}=\left(\frac{E_{U, E}}{E_{U, E 0}}-1\right) H_{E}^{U} \quad V H_{A}^{U}=\left(\frac{E_{U, A}}{E_{U, A 0}}-1\right) H_{A}^{U},
$$


where $E_{U, E 0}$ and $E_{U, A 0}$ are the initial levels of exchange rates. The valuation effects for European assets and liabilities are:

$$
\begin{array}{rlrl}
V H_{E}^{E} & =\left(\frac{E_{U, E}}{E_{U, E 0}}-1\right) H_{E}^{E} & V H_{A}^{E}=\left(\frac{E_{U, A}}{E_{U, A 0}}-1\right) H_{A}^{E} \\
V L_{E}^{E}=\left(\frac{E_{U, E}}{E_{U, E 0}}-1\right) L_{E}^{E} & V L_{A}^{E}=\left(\frac{E_{U, A}}{E_{U, A 0}}-1\right) L_{A}^{E} .
\end{array}
$$

The effects for Asian assets and liabilities are:

$$
\begin{array}{rlrl}
V H_{E}^{A} & =\left(\frac{E_{U, E}}{E_{U, E 0}}-1\right) H_{E}^{A} & V H_{A}^{A}=\left(\frac{E_{U, A}}{E_{U, A 0}}-1\right) H_{A}^{A}, \\
V L_{E}^{A} & =\left(\frac{E_{U, E}}{E_{U, E 0}}-1\right) L_{E}^{A} & V L_{A}^{A}=\left(\frac{E_{U, A}}{E_{U, A 0}}-1\right) L_{A}^{A} .
\end{array}
$$

Combining trade flows, interest payments and valuation effects gives the dynamics of the various components of the balance sheets. Denoting end-of-period positions with primes, the dynamics of the various components of U.S. assets and liabilities are:

$$
\begin{aligned}
H_{U}^{U \prime} & =H_{U}^{U}+\pi\left[r^{W} H_{U}^{U}+\mu_{E, U}^{U} G H_{E}^{U}+\mu_{A, U}^{U} G H_{A}^{U}\right] \\
H_{E}^{U \prime} & =H_{E}^{U}+\pi\left[r^{W} H_{E}^{U}+\mu_{E, E}^{U} G H_{E}^{U}+\mu_{A, E}^{U} G H_{A}^{U}+V H_{E}^{U}\right] \\
H_{A}^{U \prime} & =H_{A}^{U}+\pi\left[r^{W} H_{A}^{U}+\left(1-\mu_{E, U}^{U}-\mu_{E, E}^{U}\right) G H_{E}^{U}+\left(1-\mu_{A, U}^{U}-\mu_{A, E}^{U}\right) G H_{A}^{U}+V H_{A}^{U}\right] \\
\tilde{L}^{U \prime} & =\tilde{L}^{U}+\pi\left[r^{U} \tilde{L}^{U}+\left(G H_{U}^{E}+G H_{U}^{A}\right)\right]
\end{aligned}
$$

The dynamics of European assets and liabilities are:

$$
\begin{aligned}
H_{U}^{E \prime} & =H_{U}^{E}+\pi\left[r^{W} H_{U}^{E}+\mu_{A, U}^{E} G H_{A}^{E}\right] \\
H_{E}^{E \prime} & =H_{E}^{E}+\pi\left[r^{W} H_{E}^{E}+\mu_{A, E}^{E} G H_{A}^{E}+V H_{E}^{E}\right] \\
H_{A}^{E \prime} & =H_{A}^{E}+\pi\left[r^{W} H_{A}^{E}+\left(1-\mu_{A, U}^{E}-\mu_{A, E}^{E}\right) G H_{A}^{E}+V H_{A}^{E}\right] \\
\tilde{H}_{U}^{E \prime} & =\tilde{H}_{U}^{E}+\pi\left[r^{U} \tilde{H}_{U}^{E}+G H_{U}^{E}\right] \\
L_{U}^{E \prime} & =L_{U}^{E}+\pi\left[r^{W} L_{U}^{E}+\mu_{E, U}^{U} G H_{E}^{U}+\mu_{E, U}^{A} G H_{E}^{A}\right] \\
L_{E}^{E \prime} & =L_{E}^{E}+\pi\left[r^{W} L_{E}^{E}+\mu_{E, E}^{U} G H_{E}^{U}+\mu_{E, E}^{A} G H_{E}^{A}+V L_{E}^{E}\right] \\
L_{A}^{E \prime} & =L_{A}^{E}+\pi\left[r^{W} L_{A}^{E}+\left(1-\mu_{E, U}^{U}-\mu_{E, E}^{U}\right) G H_{E}^{U}+\left(1-\mu_{E, U}^{A}-\mu_{E, E}^{A}\right) G H_{E}^{A}+V L_{A}^{E}\right]
\end{aligned}
$$


The dynamics of Asian assets and liabilities are:

$$
\begin{aligned}
H_{U}^{A \prime} & =H_{U}^{A}+\pi\left[r^{W} H_{U}^{A}+\mu_{E, U}^{A} G H_{E}^{A}\right] \\
H_{E}^{A \prime} & =H_{E}^{A}+\pi\left[r^{W} H_{E}^{A}+\mu_{E, E}^{A} G H_{E}^{A}+V H_{E}^{A}\right] \\
H_{A}^{A \prime} & =H_{A}^{A}+\pi\left[r^{W} H_{A}^{A}+\left(1-\mu_{E, U}^{A}-\mu_{E, E}^{A}\right) G H_{E}^{A}+V H_{A}^{A}\right] \\
\tilde{H}_{U}^{A \prime} & =\tilde{H}_{U}^{A}+\pi\left[r^{U} \tilde{H}_{U}^{A}+G H_{U}^{A}\right] \\
L_{U}^{A \prime} & =L_{U}^{A}+\pi\left[r^{W} L_{U}^{A}+\mu_{A, U}^{U} G H_{A}^{U}+\mu_{A, U}^{E} G H_{A}^{E}\right] \\
L_{E}^{A \prime} & =L_{E}^{A}+\pi\left[r^{W} L_{E}^{A}+\mu_{A, E}^{U} G H_{A}^{U}+\mu_{A, E}^{E} G H_{A}^{E}+V L_{E}^{A}\right] \\
L_{A}^{A \prime} & =L_{A}^{A}+\pi\left[r^{W} L_{A}^{A}+\left(1-\mu_{A, U}^{U}-\mu_{A, E}^{U}\right) G H_{A}^{U}+\left(1-\mu_{A, U}^{E}-\mu_{A, E}^{E}\right) G H_{A}^{E}+V L_{A}^{A}\right]
\end{aligned}
$$

\section{A.4. Market clearing conditions}

\section{A.4.1. Trade flows}

In each region the value of consumption of tradable goods can be written as a function of the current account, the net interest income and the value of tradable output. Using the various consumption demands, the dollar value of gross U.S. exports can then be written as:

$$
\begin{aligned}
G H_{E}^{U} & =(\beta-\alpha)\left[\frac{P_{U}}{P_{T}^{E}}\right]^{1-\eta}\left[P_{E} Y_{T}^{E}+N I^{E}-C A^{E}\right] \\
G H_{A}^{U} & =\frac{1-\delta}{2}\left[\frac{P_{U}}{P_{T}^{A}}\right]^{1-\eta}\left[P_{A} Y_{T}^{A}-\left(N I^{U}+N I^{E}\right)+\left(C A^{U}+C A^{E}\right)\right]
\end{aligned}
$$

Using the ratios across various outputs, we express the gross trade flows are expressed in terms of ratios to the value of U.S. traded outputs, denoted by lower case letters. The U.S. exports are:

$$
\begin{aligned}
g h_{E}^{U} & =\frac{\beta-\alpha}{(\beta-\alpha)+\alpha\left(\tau_{U, E}\right)^{1-\eta}+(1-\beta)\left(\tau_{U, A}\right)^{1-\eta}}\left[\frac{\tau_{U, E}}{\sigma_{U / E}}+n i^{E}-c a^{E}\right] \\
g h_{A}^{U} & =\frac{1-\delta}{(1-\delta)+(1-\delta)\left(\tau_{U, E}\right)^{1-\eta}+2 \delta\left(\tau_{U, A}\right)^{1-\eta}}\left[\frac{\tau_{U, A}}{\sigma_{U / A}}-\left(n i^{U}+n i^{E}\right)+\left(c a^{U}+c a^{E}\right)\right]
\end{aligned}
$$

The value of European exports is:

$$
\begin{aligned}
G H_{U}^{E} & =(\beta-\alpha)\left[\frac{P_{E}}{P_{T}^{U}}\right]^{1-\eta}\left[P_{U} Y_{T}^{U}+N I^{U}-C A^{U}\right] \\
G H_{A}^{E} & =\frac{1-\delta}{2}\left[\frac{P_{E}}{P_{T}^{A}}\right]^{1-\eta}\left[P_{A} Y_{T}^{A}-\left(N I^{U}+N I^{E}\right)+\left(C A^{U}+C A^{E}\right)\right]
\end{aligned}
$$


Which become in scaled terms:

$$
\begin{aligned}
g h_{U}^{E} & =\frac{(\beta-\alpha)\left(\tau_{U, E}\right)^{1-\eta}}{\alpha+(\beta-\alpha)\left(\tau_{U, E}\right)^{1-\eta}+(1-\beta)\left(\tau_{U, A}\right)^{1-\eta}}\left[1+n i^{U}-c a^{U}\right] \\
g h_{A}^{E} & =\frac{(1-\delta)\left(\tau_{U, E}\right)^{1-\eta}}{(1-\delta)+(1-\delta)\left(\tau_{U, E}\right)^{1-\eta}+2 \delta\left(\tau_{U, A}\right)^{1-\eta}}\left[\frac{\tau_{U, A}}{\sigma_{U / A}}-\left(n i^{U}+n i^{E}\right)+\left(c a^{U}+c a^{E}\right)\right]
\end{aligned}
$$

And the value of Asian exports is:

$$
\begin{aligned}
G H_{U}^{A} & =(1-\beta)\left[\frac{P_{A}}{P_{T}^{U}}\right]^{1-\eta}\left[P_{U} Y_{T}^{U}+N I^{U}-C A^{U}\right] \\
G H_{E}^{A} & =(1-\beta)\left[\frac{P_{A}}{P_{T}^{E}}\right]^{1-\eta}\left[P_{E} Y_{T}^{E}+N I^{E}-C A^{E}\right]
\end{aligned}
$$

Which we scale by U.S. traded output as:

$$
\begin{aligned}
g h_{U}^{A} & =\frac{(1-\beta)\left(\tau_{U, A}\right)^{1-\eta}}{\alpha+(\beta-\alpha)\left(\tau_{U, E}\right)^{1-\eta}+(1-\beta)\left(\tau_{U, A}\right)^{1-\eta}}\left[1+n i^{U}-c a^{U}\right] \\
g h_{E}^{A} & =\frac{(1-\beta)\left(\tau_{U, A}\right)^{1-\eta}}{(\beta-\alpha)+\alpha\left(\tau_{U, E}\right)^{1-\eta}+(1-\beta)\left(\tau_{U, A}\right)^{1-\eta}}\left[\frac{\tau_{U, E}}{\sigma_{U / E}}+n i^{E}-c a^{E}\right]
\end{aligned}
$$

\section{A.4.2. Goods market clearing}

The market clearing conditions require the exogenous outputs of the various goods to be equal to the domestic demand and exports. The market clearing for the various tradable goods, written in terms of dollar values, are:

$$
\begin{aligned}
& P_{U} Y_{T}^{U}=\alpha\left[\frac{P_{U}}{P_{T}^{U}}\right]^{1-\eta}\left[P_{U} Y_{T}^{U}+N I^{U}-C A^{U}\right]+G H_{E}^{U}+G H_{A}^{U} \\
& P_{E} Y_{T}^{E}=\alpha\left[\frac{P_{E}}{P_{T}^{E}}\right]^{1-\eta}\left[P_{E} Y_{T}^{E}+N I^{E}-C A^{E}\right]+G H_{U}^{E}+G H_{A}^{E} \\
& P_{A} Y_{T}^{A}=\delta\left[\frac{P_{A}}{P_{T}^{A}}\right]^{1-\eta}\left[P_{A} Y_{T}^{A}-\left(N I^{U}+N I^{E}\right)+\left(C A^{U}+C A^{E}\right)\right]+G H_{U}^{A}+G H_{E}^{A}
\end{aligned}
$$

The market clearing for the non-traded good in region $i$ is:

$$
Y_{N}^{i}=(1-\gamma)\left[\frac{P_{N}^{i}}{P_{C}^{i}}\right]^{-\theta} C^{i}=\frac{1-\gamma}{\gamma}\left[\frac{P_{N}^{i}}{P_{T}^{i}}\right]^{-\theta} C_{T}^{i}
$$

The market clearing condition for the U.S. tradable goods is:

$$
1=\frac{\alpha}{\alpha+(\beta-\alpha)\left(\tau_{U, E}\right)^{1-\eta}+(1-\beta)\left(\tau_{U, A}\right)^{1-\eta}}\left[1+n i^{U}-c a^{U}\right]+g h_{E}^{U}+g h_{A}^{U}
$$


The conditions for European and Asian tradable goods are:

$$
\begin{aligned}
1 & =\frac{\sigma_{U / E}}{\tau_{U, E}}\left[g h_{U}^{E}+g h_{A}^{E}+\frac{\alpha\left(\tau_{U, E}\right)^{1-\eta}}{(\beta-\alpha)+\alpha\left(\tau_{U, E}\right)^{1-\eta}+(1-\beta)\left(\tau_{U, A}\right)^{1-\eta}}\left[\frac{\tau_{U, E}}{\sigma_{U / E}}+n i^{E}-c a^{E}\right]\right] \\
1 & =\frac{\sigma_{U / A}}{\tau_{U, A}}\left(g h_{U}^{A}+g h_{E}^{A}+\frac{2 \delta\left(\tau_{U, A}\right)^{1-\eta}}{(1-\delta)+(1-\delta)\left(\tau_{U, E}\right)^{1-\eta}+2 \delta\left(\tau_{U, A}\right)^{1-\eta}}\left[\begin{array}{c}
\frac{\tau_{U, A}}{\sigma_{U / A}}-\left(n i^{U}+n i^{E}\right) \\
+\left(c a^{U}+c a^{E}\right)
\end{array}\right]\right)
\end{aligned}
$$

The market clearing condition for the various non-traded goods are:

$$
\begin{aligned}
\sigma_{N / U}= & \frac{1-\gamma}{\gamma}\left[x^{U}\right]^{-\theta}\left[\alpha+(\beta-\alpha)\left(\tau_{U, E}\right)^{1-\eta}+(1-\beta)\left(\tau_{U, A}\right)^{1-\eta}\right]^{-\frac{1}{1-\eta}}\left[1+n i^{U}-c a^{U}\right] \\
\sigma_{N / E}= & \frac{1-\gamma}{\gamma}\left[x^{E}\right]^{-\theta}\left[\begin{array}{c}
(\beta-\alpha)\left(\tau_{U, E}\right)^{-(1-\eta)}+\alpha \\
+(1-\beta)\left(\tau_{U, A}\right)^{1-\eta}\left(\tau_{U, E}\right)^{-(1-\eta)}
\end{array}\right]^{-\frac{1}{1-\eta}}\left[1+\frac{\sigma_{U / E}}{\tau_{U, E}}\left(n i^{E}-c a^{E}\right)\right] \\
\sigma_{N / A}= & \frac{1-\gamma}{\gamma}\left[x^{A}\right]^{-\theta}\left[\frac{1-\delta}{2}\left(\tau_{U, A}\right)^{-(1-\eta)}+\frac{1-\delta}{2}\left(\tau_{U, E}\right)^{1-\eta}\left(\tau_{U, A}\right)^{-(1-\eta)}+\delta\right]^{-\frac{1}{1-\eta}} \\
& {\left[1-\frac{\sigma_{U / A}}{\tau_{U, A}}\left(n i^{U}+n i^{E}\right)+\frac{\sigma_{U / A}}{\tau_{U, A}}\left(c a^{U}+c a^{E}\right)\right] . }
\end{aligned}
$$


TABle 1: Initial StruCture of ASSEts AND Liabilities. (Trillion $\$$ )

\begin{tabular}{|c|c|c|c|}
\hline & $\begin{array}{l}\text { Assets } \\
\text { (a) }\end{array}$ & $\begin{array}{l}\text { Liabilities } \\
\text { (b) }\end{array}$ & $\begin{array}{l}\text { Net } \\
\text { (c) }\end{array}$ \\
\hline \multicolumn{4}{|l|}{ United States } \\
\hline $\begin{array}{l}\text { Total } \\
\text { - dollar } \\
\text { - euro and yen }\end{array}$ & $\begin{array}{l}8.250 \\
3.317 \\
4.934\end{array}$ & $\begin{array}{l}11.000 \\
11.000\end{array}$ & $\begin{array}{r}-2.750 \\
-7.684 \\
4.934\end{array}$ \\
\hline $\begin{array}{l}\text { High-return assets } \\
\text { - dollar } \\
\text { - euro } \\
\text { - yen }\end{array}$ & $\begin{array}{l}3.317 \\
3.341 \\
1.592\end{array}$ & & $\begin{array}{l}3.317 \\
3.341 \\
1.592\end{array}$ \\
\hline Low-return assets (dollars) & & 11.000 & -11.000 \\
\hline \multicolumn{4}{|l|}{ Europe } \\
\hline $\begin{array}{l}\text { Total } \\
\text { - dollar } \\
\text { - euro and yen }\end{array}$ & $\begin{array}{c}11.000 \\
3.520 \\
7.480\end{array}$ & $\begin{array}{l}11.000 \\
2.200 \\
8.800\end{array}$ & $\begin{array}{r}0.000 \\
1.320 \\
-1.320\end{array}$ \\
\hline $\begin{array}{l}\text { High-return assets } \\
\text { - dollar } \\
\text { - euro } \\
\text { - yen }\end{array}$ & $\begin{array}{l}0.495 \\
6.270 \\
1.210\end{array}$ & $\begin{array}{l}2.200 \\
8.800 \\
0.000\end{array}$ & $\begin{array}{r}-1.705 \\
-2.530 \\
1.210\end{array}$ \\
\hline Low-return assets (dollars) & 3.025 & & 3.025 \\
\hline \multicolumn{4}{|l|}{ Asia } \\
\hline $\begin{array}{l}\text { Total } \\
\text { - dollar } \\
\text { - euro and yen }\end{array}$ & $\begin{array}{c}11.000 \\
8.800 \\
2.200\end{array}$ & $\begin{array}{l}8.250 \\
2.437 \\
5.814\end{array}$ & $\begin{array}{r}2.750 \\
6.364 \\
-3.614\end{array}$ \\
\hline $\begin{array}{l}\text { High-return assets } \\
\text { - dollar } \\
\text { - euro } \\
\text { - yen }\end{array}$ & $\begin{array}{l}0.825 \\
2.200 \\
0.000\end{array}$ & $\begin{array}{l}2.437 \\
3.011 \\
2.802\end{array}$ & $\begin{array}{l}-1.612 \\
-0.811 \\
-2.802\end{array}$ \\
\hline Low-return assets (dollars) & 7.975 & & 7.975 \\
\hline
\end{tabular}

Note: interest rates are 5 percent on high-return assets and 3.75 on low-return assets. 
TABle 2: CURRENCY COMPOSITION OF GROSS TRADE FlOWS.

(Percent)

\begin{tabular}{lccc}
\hline \hline & $\begin{array}{c}\text { Dollar } \\
\text { (a) }\end{array}$ & $\begin{array}{c}\text { Euro } \\
\text { (b) }\end{array}$ & $\begin{array}{c}\text { Yen } \\
\text { (c) }\end{array}$ \\
\hline $\begin{array}{l}\text { Exports from the U.S. to: } \\
\text { - Europe }\end{array}$ & 50 & 50 & 0 \\
$\quad$ - Asia & 85 & 0 & 15 \\
Exports from Europe to: & & & \\
$\quad$ - U.S. & 100 & 0 & 0 \\
- Asia & 35 & 50 & 15 \\
Exports from Asia to: & & & \\
$\quad$ - U.S. & 100 & 0 & 0 \\
- Europe & 20 & 80 & 20 \\
\hline \hline
\end{tabular}

TABle 3: Parameter values.

\begin{tabular}{|c|c|c|c|}
\hline Definition & $\begin{array}{c}\text { Symbol } \\
\text { (a) }\end{array}$ & $\begin{array}{l}\text { Baseline } \\
\text { (b) }\end{array}$ & $\begin{array}{c}\text { Extensions } \\
\text { (c) }\end{array}$ \\
\hline \multicolumn{4}{|l|}{ Elasticity of substitution } \\
\hline - among traded goods & $\theta$ & 1 & \\
\hline - between traded and nontraded goods & $\eta$ & 2 & \\
\hline \multirow[t]{4}{*}{ Weights in consumption baskets } & $\alpha$ & 0.7 & \\
\hline & $\beta$ & 0.8 & \\
\hline & $\delta$ & 0.7 & \\
\hline & $\gamma$ & 0.25 & \\
\hline \multirow[t]{2}{*}{ Ratio of traded goods endowments } & $\sigma_{U / E}$ & 1 & \\
\hline & $\sigma_{U / A}$ & 1 & \\
\hline \multirow[t]{3}{*}{ Ratio of non-traded to traded endowments } & $\sigma_{N / U}$ & 3 & \\
\hline & $\sigma_{N / E}$ & 3 & \\
\hline & $\sigma_{N / A}$ & 3 & \\
\hline Interest rate on high-return bonds & $r^{W}$ & 0.05 & \\
\hline Interest rate on low-return bonds & $r^{U}$ & 0.0375 & 0.05 \\
\hline \multirow[t]{2}{*}{ Ratio of initial current accounts to U.S. traded output } & $c a^{U}$ & -0.2 & \\
\hline & $c a^{E}$ & 0.5 & \\
\hline Share of trade flows mapped into financial flows & $\pi$ & 0.5 & 0 \\
\hline
\end{tabular}


TABle 4: LONG-RUn ADJUSTMENT.

(AFTER 10 PERIODS)

\begin{tabular}{|c|c|c|c|c|c|}
\hline & O\&R global re & -balancing & Dynamic & $\begin{array}{l}\text { Gap between the } \\
\text { and O\&R glob }\end{array}$ & $\begin{array}{l}\text { amic adjustment } \\
\text { re-balancing }\end{array}$ \\
\hline & $\begin{array}{l}\text { without valuation } \\
\text { (a) }\end{array}$ & $\begin{array}{l}\text { with valuation } \\
\text { (b) }\end{array}$ & $\begin{array}{l}\text { adjustment } \\
\text { (c) }\end{array}$ & $\begin{array}{l}\text { without valuation } \\
\text { (c) } /(\mathrm{a})-1\end{array}$ & $\begin{array}{l}\text { with valuation } \\
\text { (c) } /(\mathrm{b})-1\end{array}$ \\
\hline & \multicolumn{5}{|c|}{ Real depreciation of the dollar } \\
\hline Against the euro & $33.5 \%$ & $28.7 \%$ & $27.0 \%$ & $-19.3 \%$ & $-5.9 \%$ \\
\hline \multirow[t]{2}{*}{ Against the yen } & $40.8 \%$ & $34.8 \%$ & $33.6 \%$ & $-17.7 \%$ & $-3.3 \%$ \\
\hline & \multicolumn{5}{|c|}{ Effective real depreciations } \\
\hline Dollar & $38.4 \%$ & $32.7 \%$ & $31.4 \%$ & $-18.1 \%$ & $-4.1 \%$ \\
\hline Euro & $-6.3 \%$ & $-5.5 \%$ & $-4.6 \%$ & $-26.7 \%$ & $-16.9 \%$ \\
\hline \multirow[t]{2}{*}{ Yen } & $-24.1 \%$ & $-20.4 \%$ & $-20.1 \%$ & $-16.5 \%$ & $-1.5 \%$ \\
\hline & \multicolumn{5}{|c|}{ Change in aggregate consumption } \\
\hline U.S. & $-5.6 \%$ & $-4.9 \%$ & $-4.7 \%$ & $-19.7 \%$ & $-4.6 \%$ \\
\hline Europe & $2.0 \%$ & $1.8 \%$ & $1.6 \%$ & $-19.2 \%$ & $-9.7 \%$ \\
\hline Asia & $4.8 \%$ & $4.1 \%$ & $4.1 \%$ & $-15.0 \%$ & $-1.5 \%$ \\
\hline
\end{tabular}

O\&R global rebalancing without valuation: all current accounts go to zero in one period; initial positions are all in dollars.

O\&R global rebalancing with valuation: all current accounts go to zero in one period; initial positions are as in Table 1.

Dynamic adjustment: current accounts gradually go to zero leaving the dollar value of net positions unchanged; initial positions are as in Table 1.

TABle 5: FinAl NET international InVESTMENT POSITIONS.

(Percent of U.S. traded output)

\begin{tabular}{lccc}
\hline \hline & $\begin{array}{c}\text { U.S. } \\
(\mathrm{a})\end{array}$ & $\begin{array}{c}\text { Europe } \\
\text { (b) }\end{array}$ & $\begin{array}{c}\text { Asia } \\
\text { (c) }\end{array}$ \\
\hline Initial situation & -100 & 0 & 100 \\
O\&R global rebalancing & -29 & -11 & 40 \\
Dynamic adjustment & -90 & 0 & 90 \\
\hline \hline
\end{tabular}

O\&R rebalancing: all current accounts go to zero in one period; initial positions are as in Table 1. Dynamic adjustment: current accounts gradually go to zero leaving the dollar value of net positions unchanged; initial positions are as in Table 1. 
TABle 6: Gross positions.

(Trillion $\$$ )

\begin{tabular}{llccc}
\hline \hline \multirow{7}{*}{ US total } & & $\begin{array}{c}\text { Initial } \\
\text { positions } \\
(\mathrm{a})\end{array}$ & $\begin{array}{c}\text { Long-run } \\
\text { positions } \\
(\mathrm{b})\end{array}$ & $\begin{array}{c}\text { Ratio } \\
(\mathrm{b}) /(\mathrm{a})\end{array}$ \\
\hline \multirow{4}{*}{ US non-dollar } & Assets & 8.25 & 15.70 & 1.9 \\
& Liabilities & 11.00 & 18.45 & 1.7 \\
& Net & -2.75 & -2.75 & 1.0 \\
& Assets & 4.93 & 8.50 & 1.7 \\
& Liabilities & 0.00 & 0.00 & \\
Europe total & Net & 4.93 & 8.50 & 1.7 \\
& & & & \\
& Assets & 11.00 & 20.08 & 1.8 \\
& Liabilities & 11.00 & 20.08 & 1.8 \\
& Net & 0.00 & 0.00 & \\
& Assets & 7.48 & 12.95 & 1.7 \\
& Liabilities & 8.80 & 15.98 & 1.8 \\
& Net & -1.32 & -3.03 & 2.3 \\
& & & & \\
Asia total & Assets & 11.00 & 20.04 & 1.8 \\
& Liabilities & 8.25 & 17.29 & 2.1 \\
& Net & 2.75 & 2.75 & 1.0 \\
& Assets & 2.20 & 5.51 & 2.5 \\
& Liabilities & 5.81 & 10.98 & 1.9 \\
& Net & -3.61 & -5.47 & 1.5 \\
\hline \hline
\end{tabular}

Long-run positions are taken 10 periods (years) after the beginning of the adjustment. 


\section{TABle 7: Long-RUn ADJustment. (AFTER 10 PERIODS)}

\begin{tabular}{|c|c|c|c|c|c|}
\hline & \multirow{2}{*}{$\begin{array}{c}\text { Baseline } \\
\text { dynamic } \\
\text { adjustment } \\
\text { (a) }\end{array}$} & \multirow[b]{2}{*}{$\begin{array}{c}\text { No gross } \\
\text { financial flows } \\
\text { (b) }\end{array}$} & \multirow[b]{2}{*}{$\begin{array}{l}\text { Convergence of } \\
\text { interest rates } \\
\text { (c) }\end{array}$} & \multicolumn{2}{|c|}{ Gap between the baseline and } \\
\hline & & & & $\begin{array}{c}\text { No gross } \\
\text { financial flows } \\
(\mathrm{d})=(\mathrm{b}) /(\mathrm{a})-1\end{array}$ & $\begin{array}{l}\text { Convergence of } \\
\text { interest rates } \\
(\mathrm{e})=(\mathrm{c}) /(\mathrm{a})-1\end{array}$ \\
\hline & \multicolumn{5}{|c|}{ Real depreciation of the dollar } \\
\hline Against the euro & $27.0 \%$ & $31.6 \%$ & $36.3 \%$ & $17.2 \%$ & $34.5 \%$ \\
\hline \multirow[t]{2}{*}{ Against the yen } & $33.6 \%$ & $38.5 \%$ & $44.0 \%$ & $14.5 \%$ & $30.8 \%$ \\
\hline & \multicolumn{5}{|c|}{ Effective real depreciations } \\
\hline Dollar & $31.4 \%$ & $36.2 \%$ & $41.4 \%$ & $15.3 \%$ & $31.8 \%$ \\
\hline Euro & $-4.6 \%$ & $-6.0 \%$ & $-7.0 \%$ & $30.7 \%$ & $53.1 \%$ \\
\hline \multirow[t]{2}{*}{ Yen } & $-20.1 \%$ & $-22.7 \%$ & $-25.8 \%$ & $12.7 \%$ & $28.2 \%$ \\
\hline & \multicolumn{5}{|c|}{ Change in aggregate consumption } \\
\hline U.S. & $-4.7 \%$ & $-5.5 \%$ & $-6.3 \%$ & $16.9 \%$ & $35.5 \%$ \\
\hline Europe & $1.6 \%$ & $2.0 \%$ & $2.2 \%$ & $19.1 \%$ & $33.9 \%$ \\
\hline Asia & $4.1 \%$ & $4.5 \%$ & $5.1 \%$ & $11.4 \%$ & $24.9 \%$ \\
\hline
\end{tabular}

Baseline adjustment: gross financial flows amount to 50 percent of corresponding trade flows, interest rate on U.S. liabilities remains at 3.75 percent.

No gross financial flows: gross financial flows amount to zero, interest rate on U.S. liabilities remains at 3.75 percent. Convergence of interest rates: gross financial flows amount to 50 percent of corresponding gross trade flows, interest rate on U.S. liabilities increases to 5 percent from the first period. 
Table 8: Gross positions With CONVERGEnCE of interest Rates. (Trillion $\$$ )

\begin{tabular}{|c|c|c|c|c|}
\hline & & $\begin{array}{c}\text { Initial } \\
\text { positions } \\
\text { (a) }\end{array}$ & $\begin{array}{l}\text { Long-run } \\
\text { positions with } \\
\text { convergence of } \\
\text { interest rates } \\
\text { (b) }\end{array}$ & $\begin{array}{l}\text { Ratio } \\
(\mathrm{b}) /(\mathrm{a})\end{array}$ \\
\hline \multirow[t]{3}{*}{ US total } & Assets & 8.25 & 16.54 & 2.0 \\
\hline & Liabilities & 11.00 & 19.29 & 1.8 \\
\hline & Net & -2.75 & -2.75 & 1.0 \\
\hline \multirow[t]{3}{*}{ US non-dollar } & Assets & 4.93 & 9.02 & 1.8 \\
\hline & Liabilities & 0.00 & 0.00 & \\
\hline & Net & 4.93 & 9.02 & 1.8 \\
\hline \multirow[t]{3}{*}{ Europe total } & Assets & 11.00 & 21.12 & 1.9 \\
\hline & Liabilities & 11.00 & 21.12 & 1.9 \\
\hline & Net & 0.00 & 0.00 & \\
\hline \multirow[t]{3}{*}{ Europe non-dollar } & Assets & 7.48 & 13.68 & 1.8 \\
\hline & Liabilities & 8.80 & 16.91 & 1.9 \\
\hline & Net & -1.32 & -3.23 & 2.4 \\
\hline \multirow[t]{3}{*}{ Asia total } & Assets & 11.00 & 21.05 & 1.9 \\
\hline & Liabilities & 8.25 & 18.30 & 2.2 \\
\hline & Net & 2.75 & 2.75 & 1.0 \\
\hline \multirow[t]{3}{*}{ Asia non-dollar } & Assets & 2.20 & 5.87 & 2.7 \\
\hline & Liabilities & 5.81 & 11.67 & 2.0 \\
\hline & Net & -3.61 & -5.80 & 1.6 \\
\hline
\end{tabular}

Long-run positions are taken 10 periods (years) after the beginning of the adjustment. 
Table 9: Cumulative flows and valuation gains

(TRILlion \$)

\begin{tabular}{|c|c|c|c|c|c|}
\hline & $\begin{array}{c}\text { Baseline } \\
\text { dynamic } \\
\text { adjustment } \\
\text { (a) }\end{array}$ & $\begin{array}{c}\text { No gross } \\
\text { financial flows } \\
\text { (b) }\end{array}$ & $\begin{array}{l}\text { Convergence of } \\
\text { interest rates } \\
\text { (c) }\end{array}$ & $\begin{array}{l}\text { Gap between } \\
\text { No gross } \\
\text { financial flows } \\
(\mathrm{d})=(\mathrm{b})-(\mathrm{a}) \\
\end{array}$ & $\begin{array}{l}\text { he baseline and } \\
\text { Convergence of } \\
\text { interest rates } \\
(\mathrm{e})=(\mathrm{c})-(\mathrm{a})\end{array}$ \\
\hline & \multicolumn{5}{|c|}{ Cumulative valuation gain } \\
\hline U.S. & 1.82 & 1.80 & 2.52 & -0.02 & 0.71 \\
\hline Europe & -0.38 & -0.36 & -0.56 & 0.02 & -0.18 \\
\hline \multirow[t]{2}{*}{ Asia } & -1.44 & -1.44 & -1.96 & 0.00 & -0.52 \\
\hline & \multicolumn{5}{|c|}{ Cumulative net interest income } \\
\hline U.S. & 0.41 & 0.00 & -1.38 & -0.41 & -1.78 \\
\hline Europe & -0.52 & -0.38 & 0.00 & 0.14 & 0.52 \\
\hline \multirow[t]{2}{*}{ Asia } & 0.11 & 0.38 & 1.38 & 0.27 & 1.27 \\
\hline & \multicolumn{5}{|c|}{ Cumulative trade balance } \\
\hline U.S. & -2.23 & -1.80 & -1.15 & 0.43 & 1.08 \\
\hline Europe & 0.89 & 0.74 & 0.56 & -0.16 & -0.33 \\
\hline Asia & 1.33 & 1.06 & 0.59 & -0.27 & -0.75 \\
\hline
\end{tabular}

All amounts represent total amounts between the initial period and period 10 .

Valuations gains: total amounts transferred through the valuation effect of exchange rate movements.

Net interest income: total amounts transferred through interest receipts net of payments.

Trade balance: total amounts transferred through exports net of imports. 


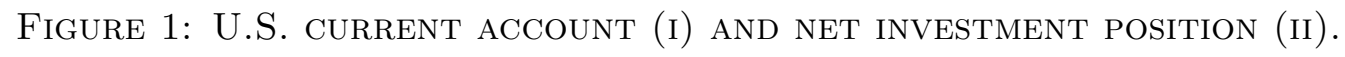

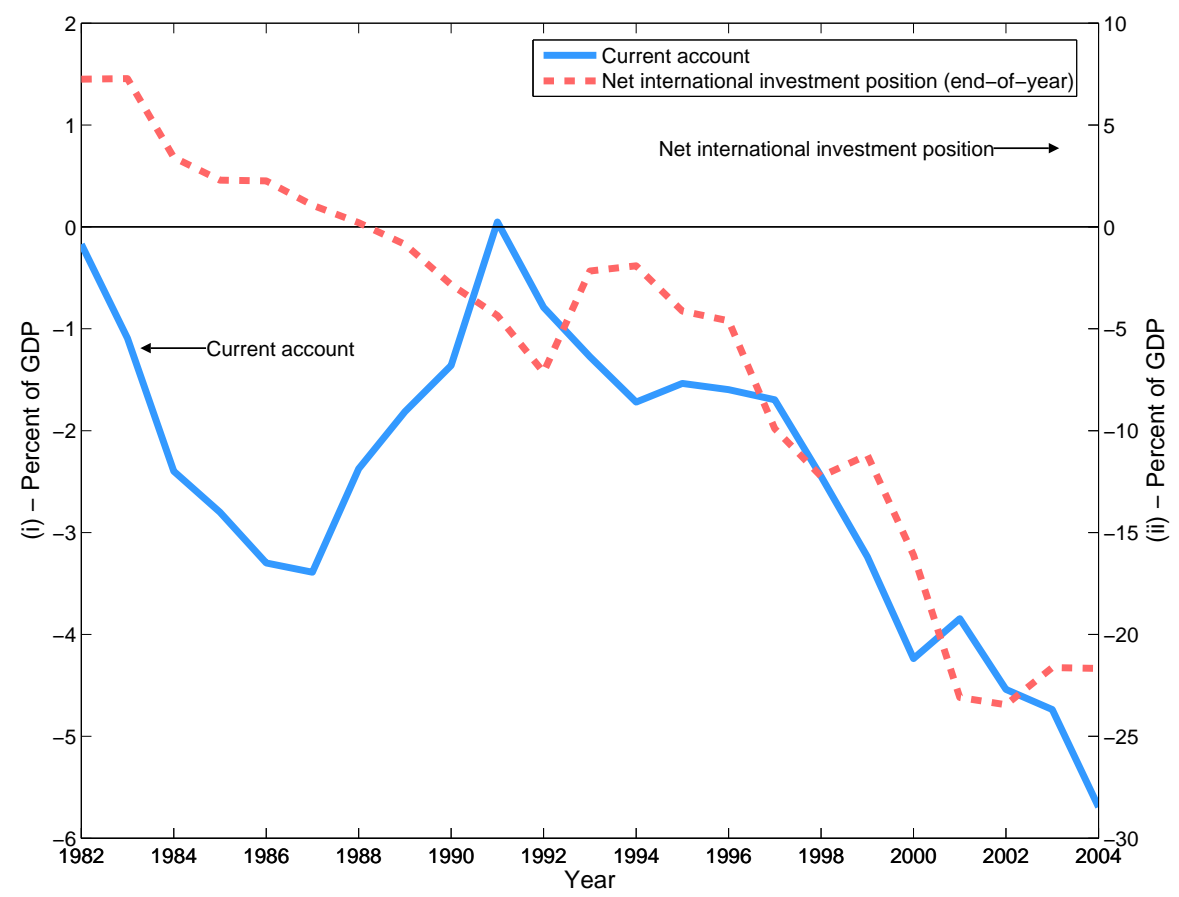

Figure 2: CHANGE IN U.S. NET INVESTMENT POSITION.

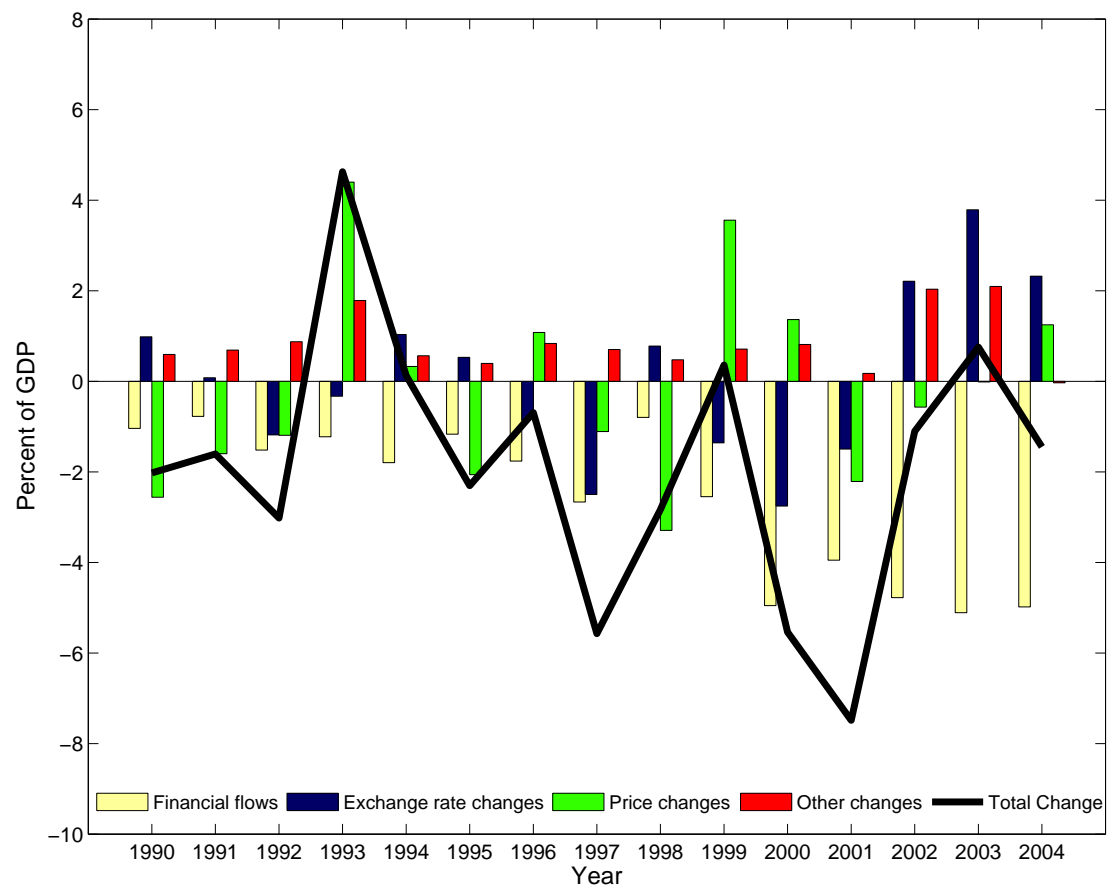

Note: Source: Bureau of Economic Analysis, International Economic Accounts. 
FigURE 3: U.S. RATIO OF GROSS FINANCIAL FLOWS TO GROSS TRADE FLOWS.

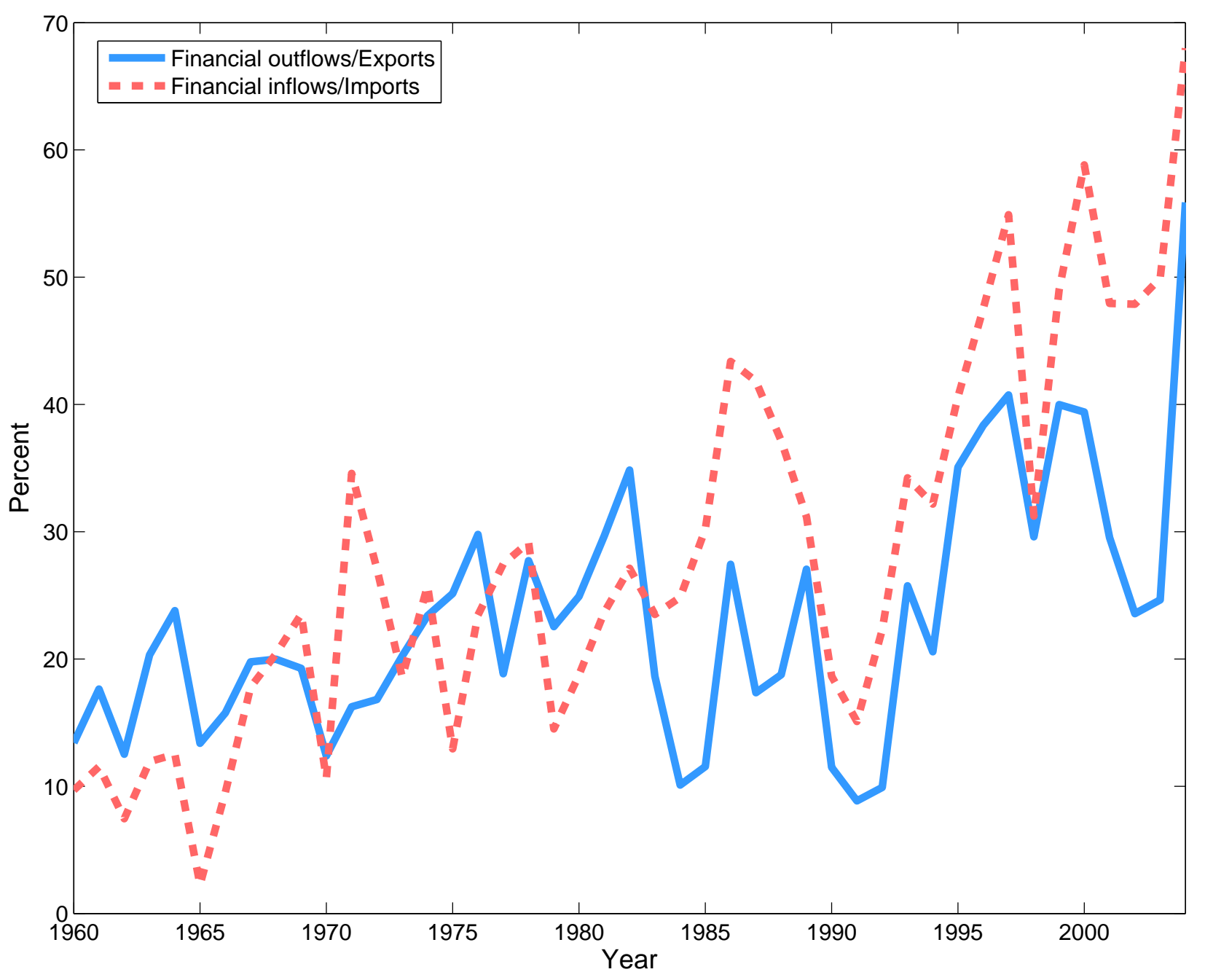

Note: Source: Bureau of Economic Analysis, International Economic Accounts. 
Figure 4: DyNAMiC ADJUSTMENT — CURRENT ACCOUNTS.

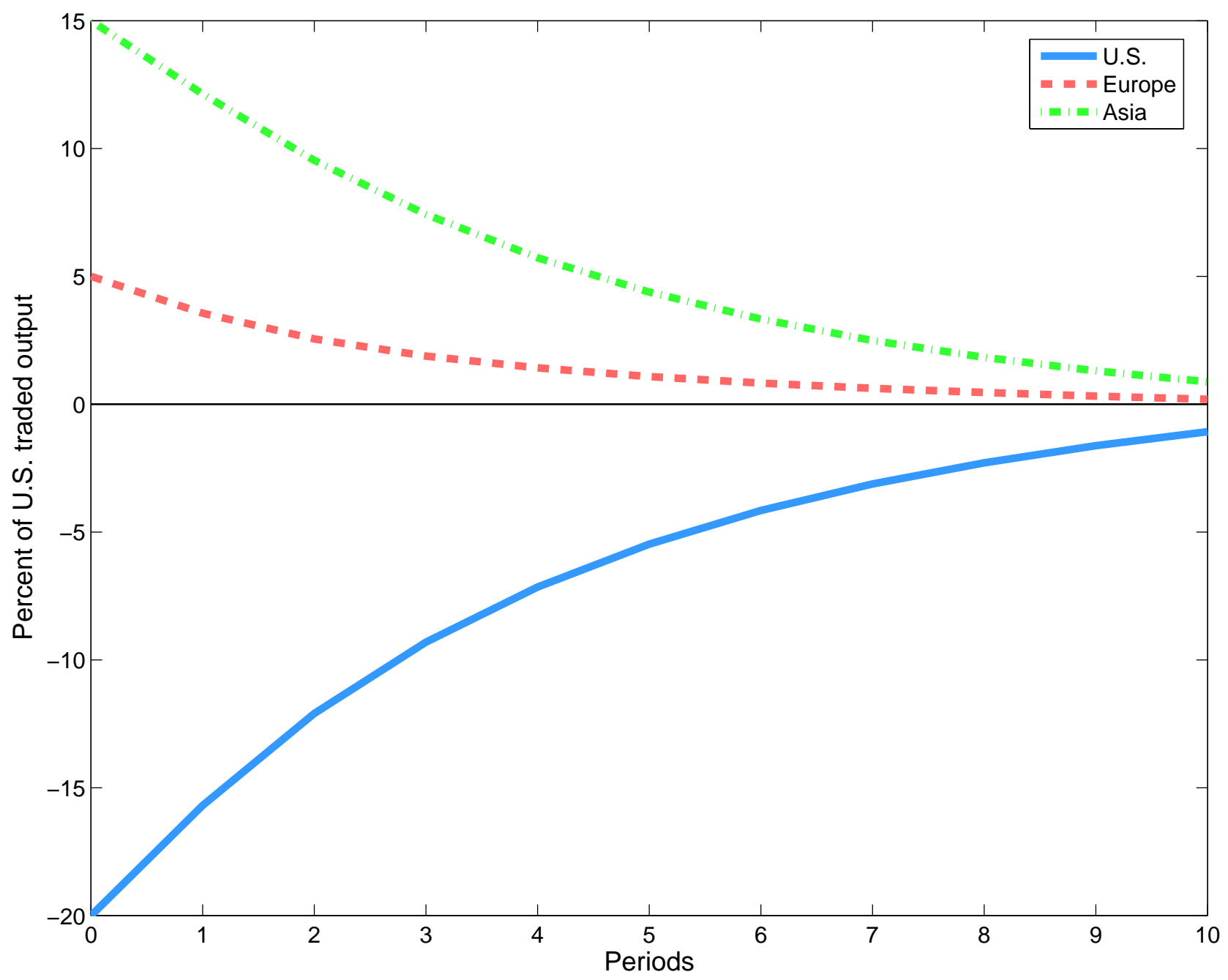


Figure 5: ReAl EXChange RAte movements.
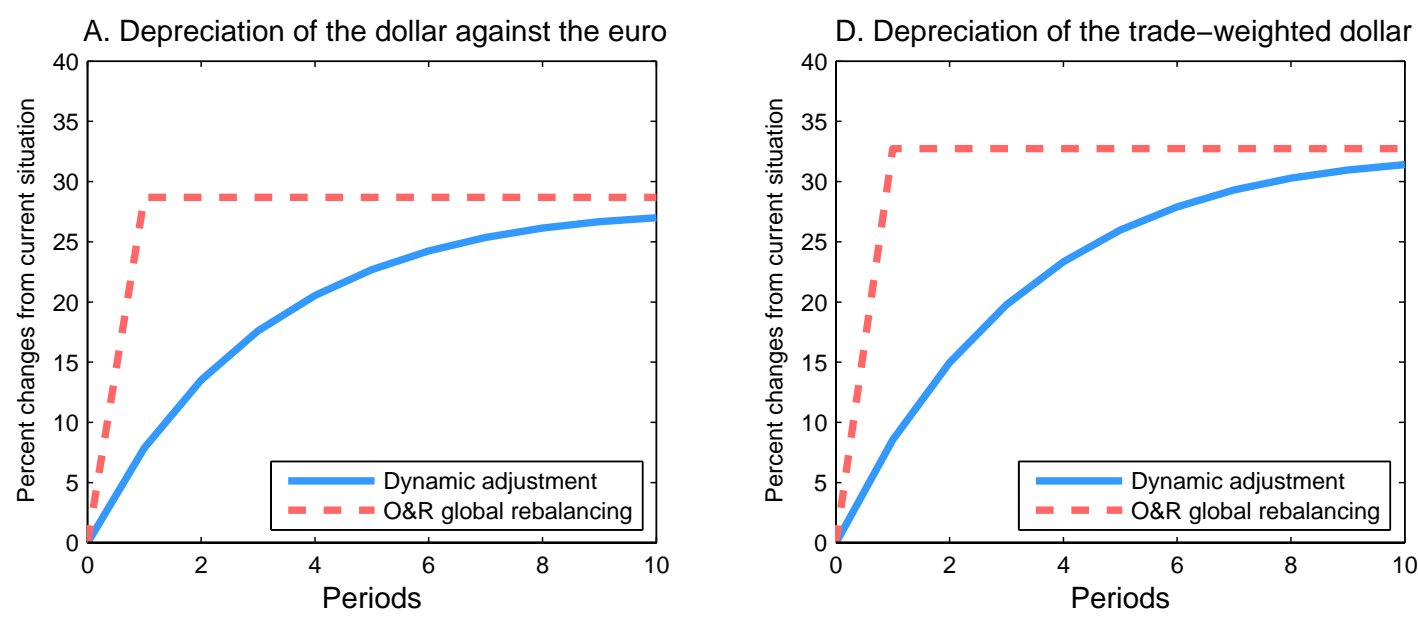

B. Depreciation of the dollar against the yen
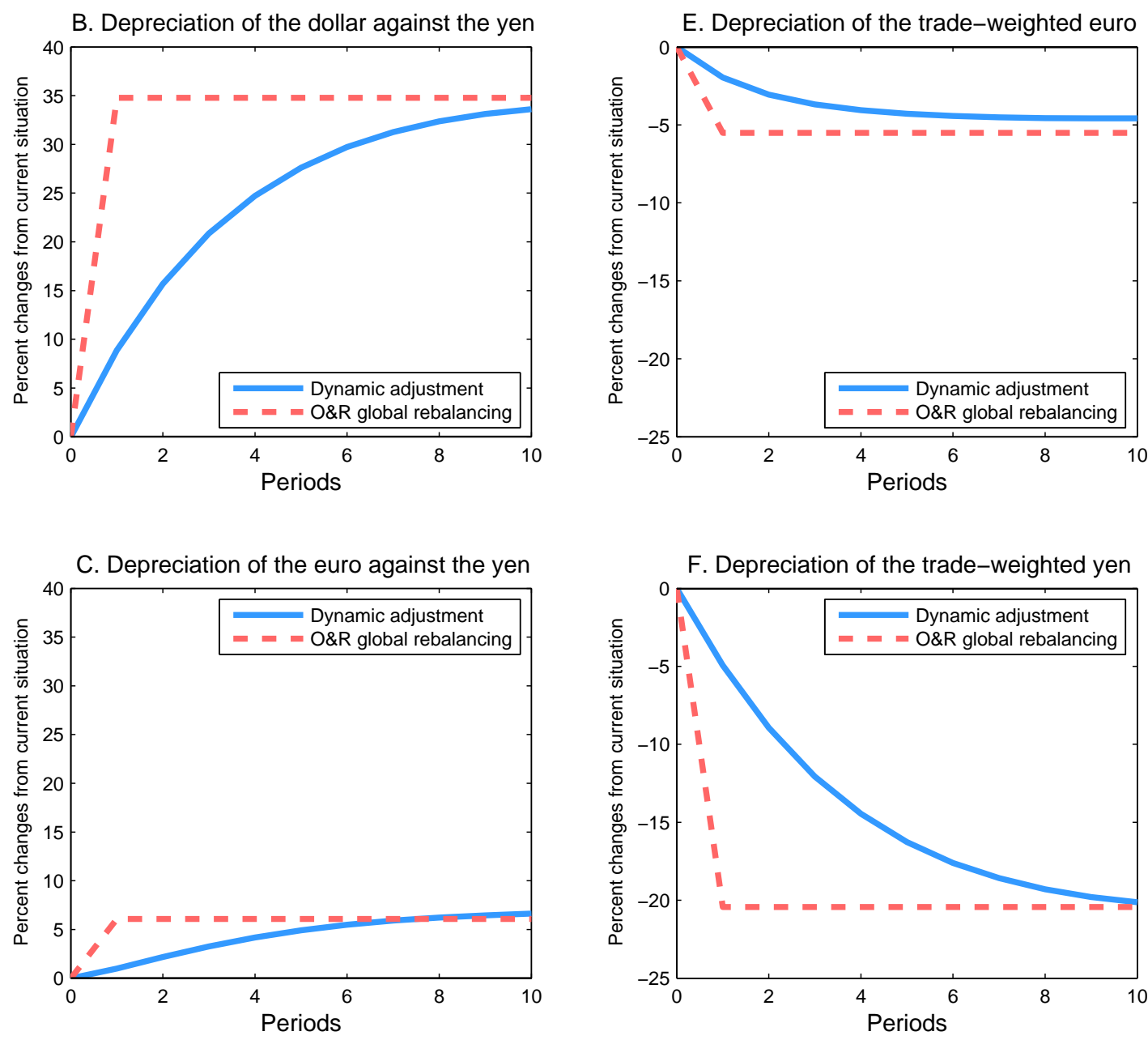
Figure 6: Dynamic adjustment - Cumulative valuation EFFECts.

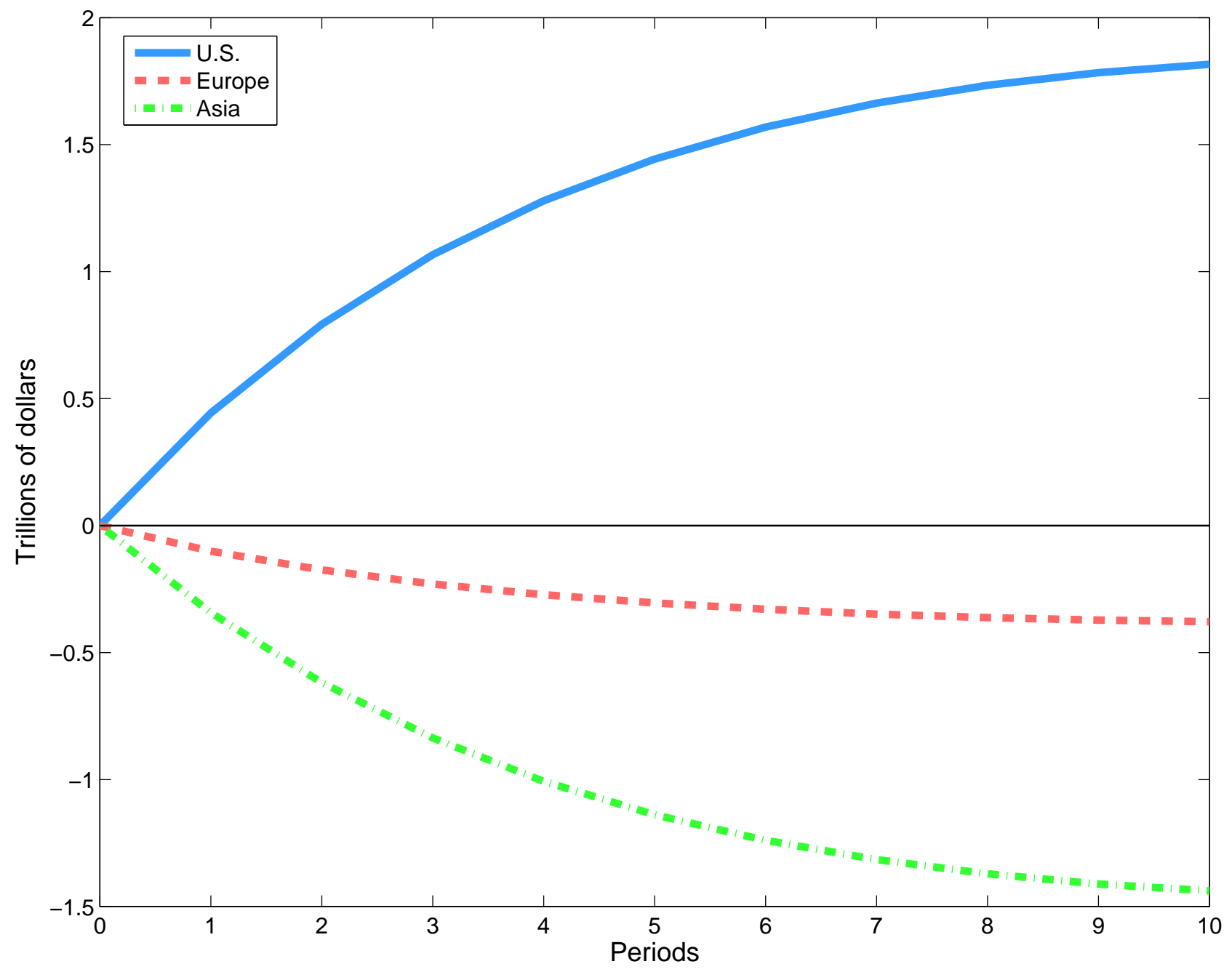


Figure 7: U.S. GROSS POSITIONS.

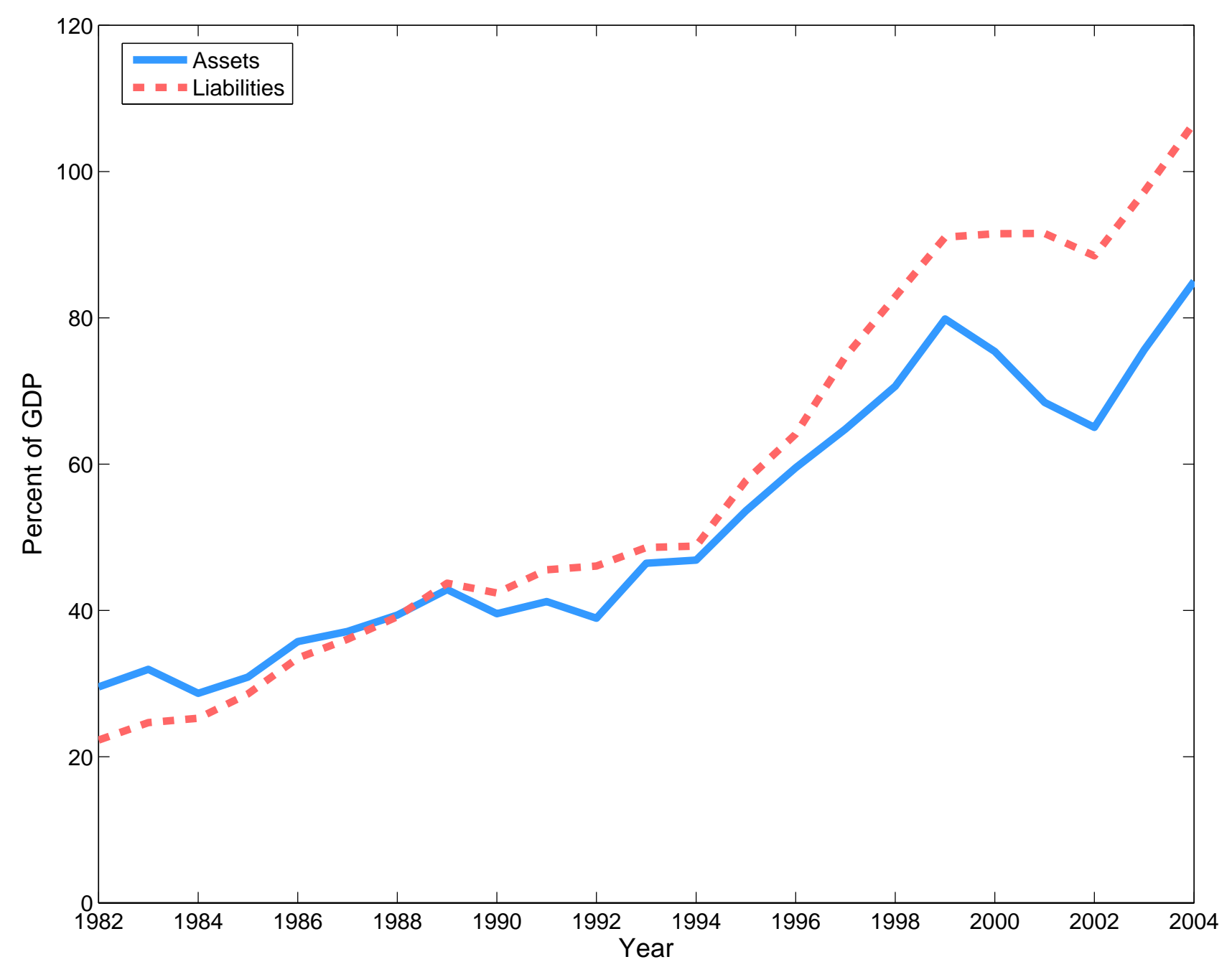

Note: Source: Bureau of Economic Analysis, International Economic Accounts. 
Figure 8: COMPONENTS OF The U.S. CURRENT ACCOUNT.

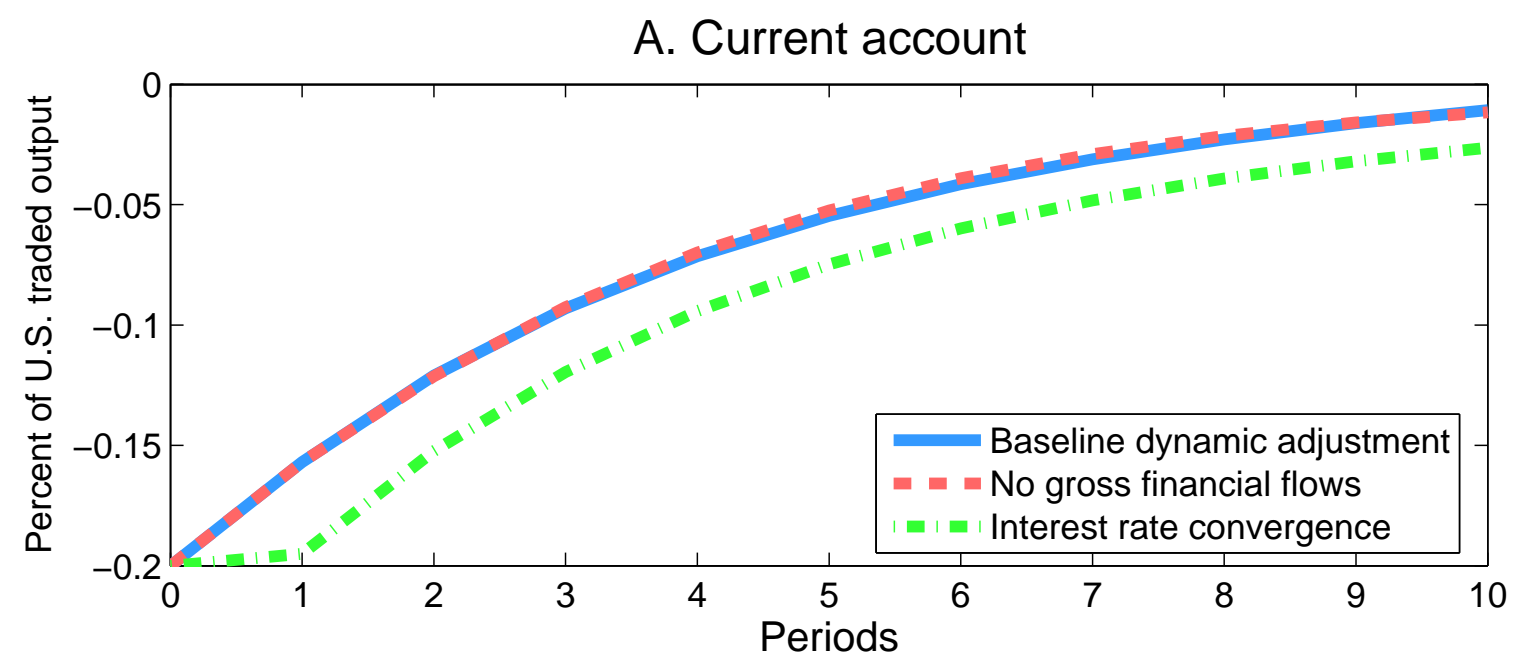

B. Net interest income

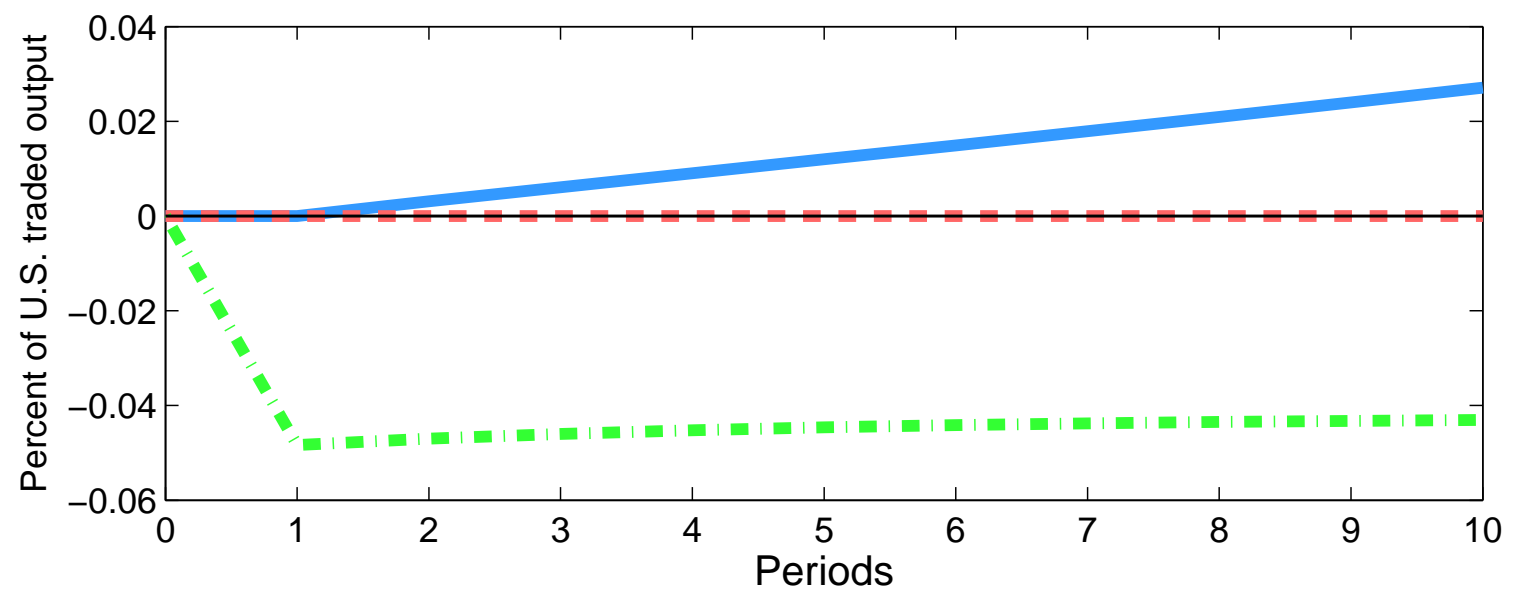

C. Trade balance

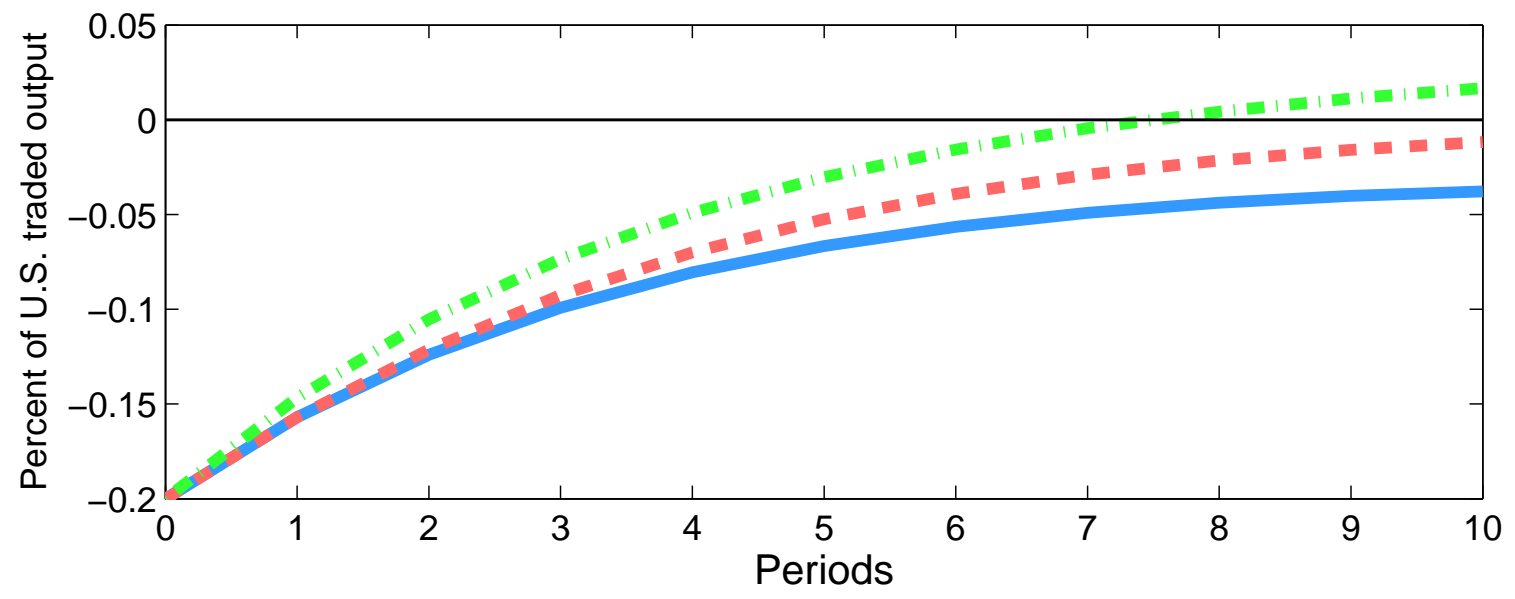


Figure 9: COMPONENTS of the EuRopean CURRENT ACCOUNT.

A. Current account

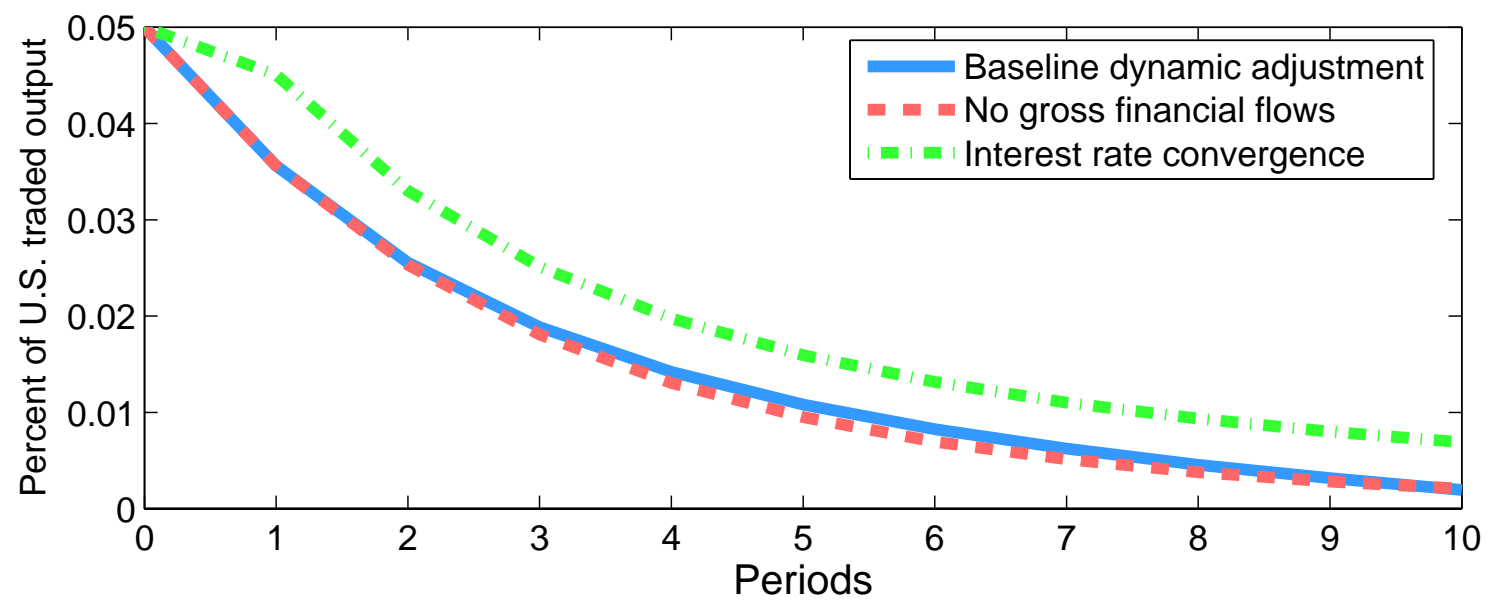

B. Net interest income

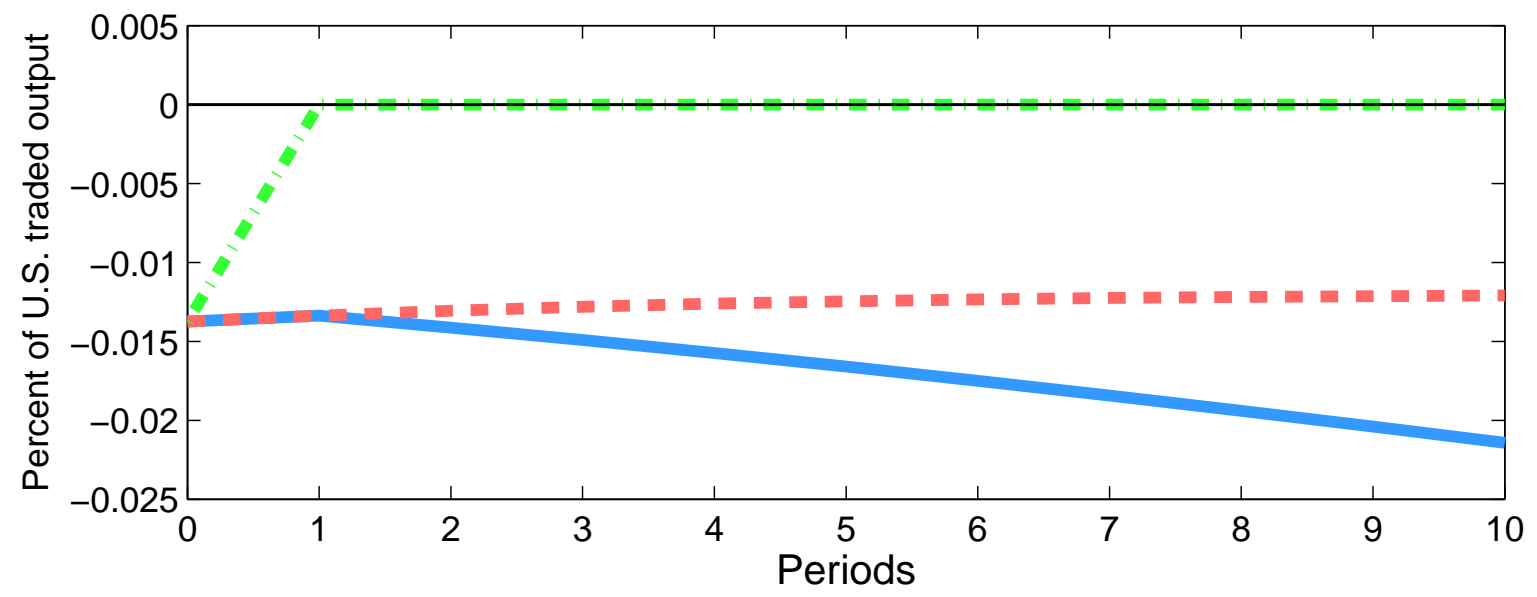

C. Trade balance

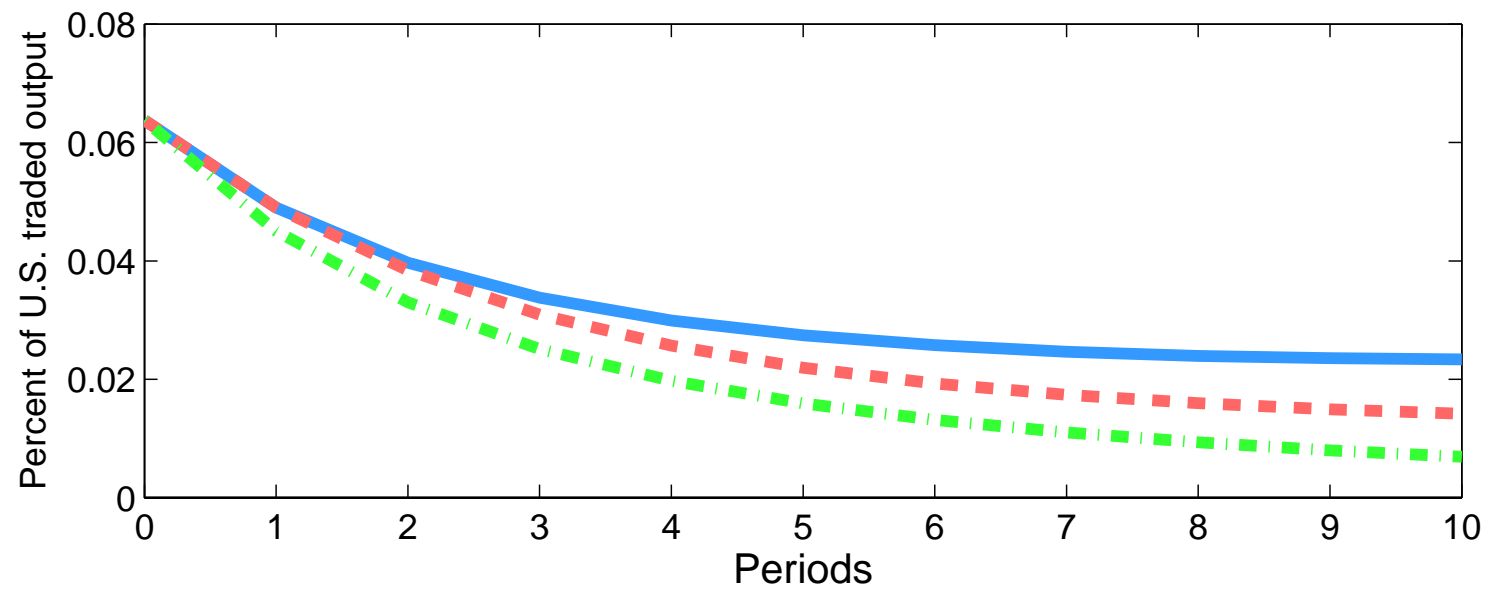


Figure 10: COMponents of the Asian CURREnt ACCOUnt.

\section{A. Current account}

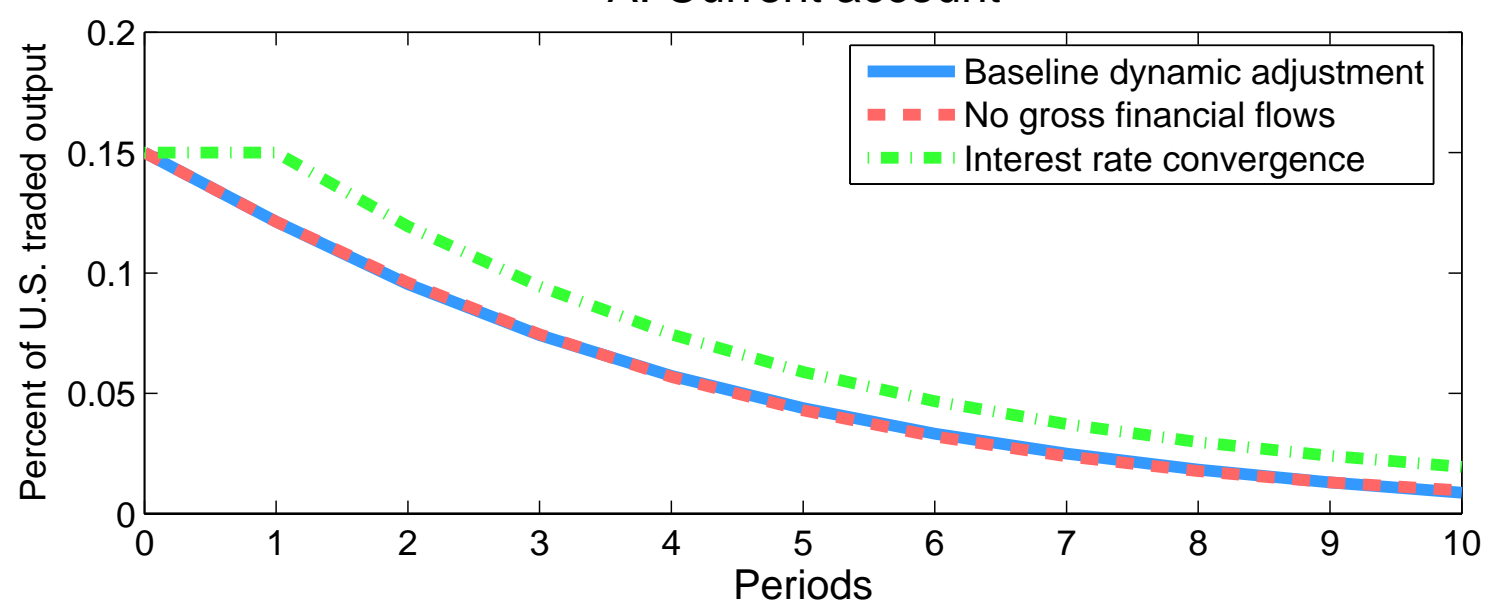

B. Net interest income

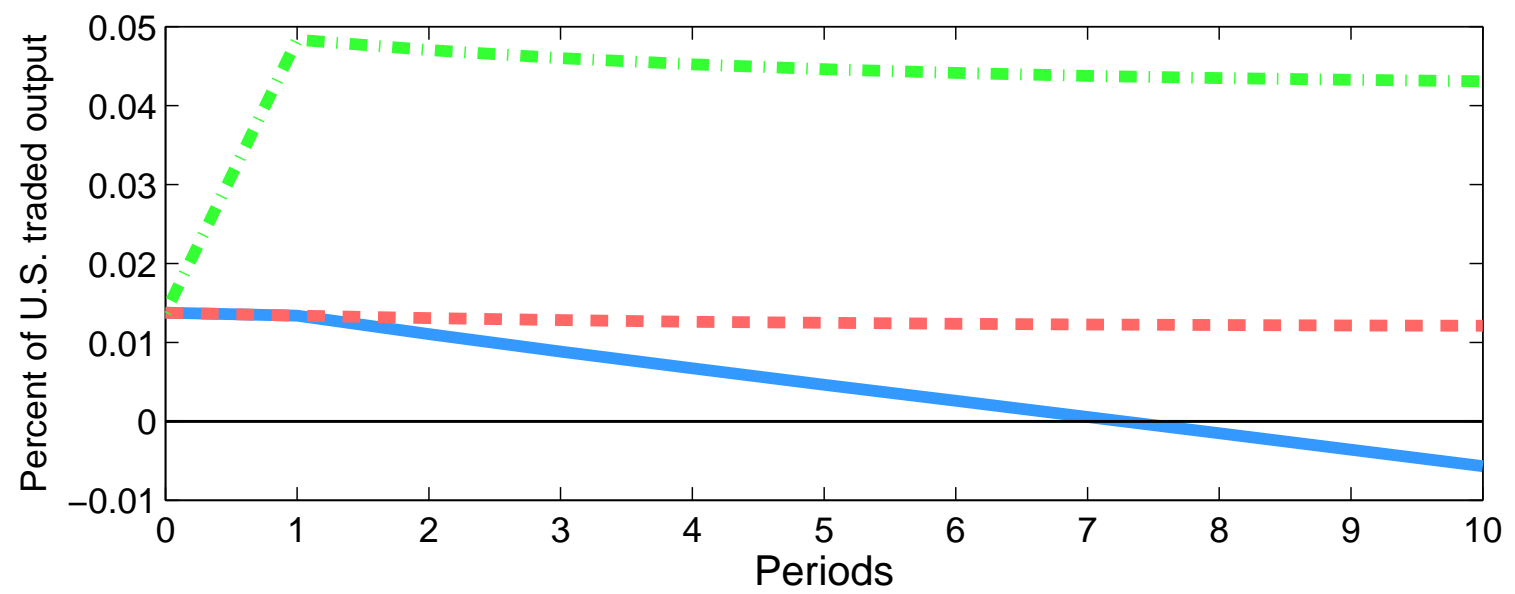

C. Trade balance

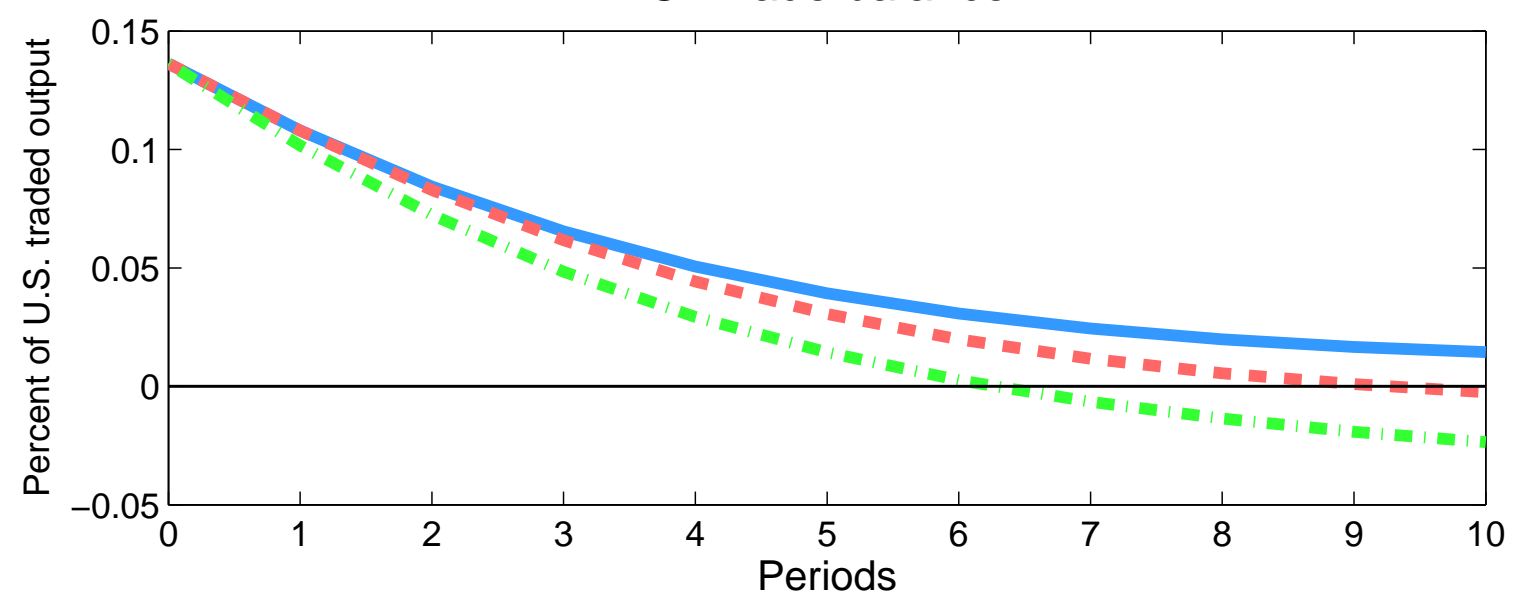

